\title{
Article \\ Effects of Incorporating Rail Transport into a Zero-Emission Urban Deliveries System: Application of Light Freight Railway (LFR) Electric Trains
}

\author{
Krystian Pietrzak*(D), Oliwia Pietrzak*(D) and Andrzej Montwiłł
}

check for

updates

Citation: Pietrzak, K.; Pietrzak, O.; Montwiłl, A. Effects of Incorporating Rail Transport into a Zero-Emission Urban Deliveries System: Application of Light Freight Railway (LFR) Electric Trains. Energies 2021, 14, 6809. https://doi.org/10.3390/en14206809

Academic Editors: Stanisław Iwan, Kinga Kijewska and

Krzysztof Małecki

Received: 30 August 2021

Accepted: 14 October 2021

Published: 18 October 2021

Publisher's Note: MDPI stays neutral with regard to jurisdictional claims in published maps and institutional affiliations.

Copyright: (c) 2021 by the authors. Licensee MDPI, Basel, Switzerland. This article is an open access article distributed under the terms and conditions of the Creative Commons Attribution (CC BY) license (https:// creativecommons.org/licenses/by/ $4.0 /)$.
Faculty of Engineering and Economics of Transport, Maritime University of Szczecin, Wały Chrobrego 1-2 Str., 70-500 Szczecin, Poland

* Correspondence: k.pietrzak@am.szczecin.pl (K.P.); o.pietrzak@am.szczecin.pl (O.P.)

\begin{abstract}
This paper addresses the issue of incorporating rail transport into an urban delivery system. Its main purpose was to identify the possibilities of utilising rail transport in a Zero-emission Urban Delivery System (ZUDS) by applying Light Freight Railway (LFR) electric trains. The study applied the following research methods: literature review, observation, case study, and mathematical computations. In order to estimate the volume of transport external costs reduction resulting from shifting urban deliveries from road to rail transport in the city of Szczecin, the EU methodology was applied to specify the amounts of external costs generated by individual modes and means of transport. The research study showed that application of LFR electric trains makes it possible to significantly reduce external costs generated by transport. Moreover, this solution may have an impact on developing Clean Transport Zones (CTZs) and may also contribute to expansion of the ZUDS. The research study results also provide grounds to conclude that application of the LFR system makes it possible to reduce negative effects generated by Urban Freight Transport (UFT) and to achieve a coherent zero-emission system for handling cargo and passenger flows in cities, which consequently contributes to achieving electromobility goals in transport.
\end{abstract}

Keywords: electromobility; electric vehicles; zero-emission vehicles; sustainable urban freight transport; city logistics; light freight railway; urban consolidation centre; last-mile delivery; external costs of transport

\section{Introduction}

Observation of demographic processes occurring worldwide indicates that the dominating trend of the 21st century is urbanisation [1]. According to forecasts, $68 \%$ of the global population will be living in cities by 2050 (currently the rate is ca. 55\%) [2]. Cities play diverse functions in all societies [3]. The intensive growth of cities is accompanied by intensive development of transport systems to handle both passenger and freight flows. The consequences of transport growth in cities may be of positive or negative nature. The positive aspects of urban transport development are mainly related to the free flow of passengers and goods: flexible and effective in meeting the community's needs, economic growth of cities and regions, and their integration. Unfortunately, the intensive growth of transport also entails problems, the most significant of which include:

- Environmental pollution as a result of emissions of harmful substances such as NOx, $\mathrm{CO}, \mathrm{CO}_{2}, \mathrm{PM}_{10}, \mathrm{PM}_{2.5}$, and $\mathrm{SO}_{2}$ [4-11];

- Global warming resulting from increased levels of $\mathrm{CO}_{2}$ in the atmosphere [12-15];

- $\quad$ Generating excessive noise [16,17];

- Negative impacts on human health, which contribute to respiratory and circulatory system diseases and cancer [18-21];

- Road congestion [22-26];

- $\quad$ Excessive number of traffic accidents and ensuing increase in social costs [27-30]; 
- $\quad$ Land consumption and land-use change $[31,32]$.

In view of these negative phenomena ensuing from the intensive growth of transport, particularly in urban areas, it becomes necessary to search for transport solutions that mitigate and prevent such problems. A significant task in this regard is a shift to lowemission mobility. A European Strategy for Low-Emission Mobility, adopted by the European Union (EU), points to three key areas regarding transport: higher efficiency of the transport system, low-emission alternative energy for transport, low- and zeroemission vehicles [33]. Electrification of (particularly urban) transport has become one of the priorities of the EU and Polish transport policies, as well as an important element of developing a zero-emission transport system.

As a result of analysing the needs and problems of European cities concerning development of zero-emission transport systems, the main goal of this article is to identify possibilities of utilising rail transport in a Zero-emission Urban Delivery System (ZUDS).

To achieve the indicated goal, the following research questions (RQs) were formulated:

- RQ1. Does utilisation of rail transport in the urban delivery system make it possible to reduce external costs generated by transport?

- RQ2. Can utilisation of rail transport in the urban delivery system have an impact on the way Clean Transport Zones (CTZs) are developed in the city?

- RQ3. Can application of Light Freight Railway (LFR) become a factor enabling expansion of the ZUDS?

The remaining part of this paper is divided into seven chapters. The literature background and the current literature concerning changes observed in Urban Freight Transport (UFT), resulting from the need to mitigate its negative effects, are presented in the Literature Review, Chapter 2. Chapter 3 presents the research process divided into its individual stages and indicates the input data applied in the study. Chapter 4 contains the spatial and functional description of the area covered by the research - the city of Szczecin, Poland. This section also describes the transport infrastructure and the current urban delivery system in Szczecin. Chapter 5 of this article outlines the original concept of Light Freight Railway (LFR) and describes the operation system of LFR trains in the railway network. Chapter 6 is the key part of this paper. It contains the results of the study of effects of incorporating rail transport into the ZUDS, based on the example of the city of Szczecin, Poland. The first item of the chapter enumerates the assumptions adopted for this study and describes the two variants to be researched: V0 and V1. The second part of Chapter 6 presents the transport external costs computation results for the research variants adopted in the city of Szczecin, and the possible level of external costs reduction. The third part of Chapter 6 identifies the other effects that may be obtained as a result of shifting urban deliveries from road to rail transport in the city of Szczecin. Chapter 7 contains the discussion of the results and it also points out the limitations of the proposed solution. The article ends with conclusions contained in the last chapter.

\section{Literature Review}

Dynamically developing transport, including in particular urban transport, generates numerous threats to the natural environment together with human life and health. Effects of adverse changes intensify due to, inter alia, the growing populations and the ensuing increase in the demand for urban mobility and urban logistics $[34,35]$, changes in the life styles resulting in new transport needs [36], or ever increasing expectations of customers regarding the quality and lead time of transport services [37]. Additionally, there are adverse climate changes connected with the fact that fossil fuels still play the dominant role in transport [38].

Therefore, it is necessary to take steps aimed at mitigating the negative effects of UFT. These include in particular:

- More effective utilisation of transport means and infrastructure;

- Preference for the transport modes that are less adverse to the environment; 
- Development of new kinds of vehicles;

- Development of new ways of freight movement and delivery.

Moreover, according to Hlali et al. [39], efficiency of a logistic chain is strongly dependent on the extent of coordination between all the participating entities. The list of indicated counteracting measures should then be supplemented with the ones that initiate or improve the cooperation between the private and public sector stakeholders.

Analysing the available literature, it is possible to notice many interesting solutions regarding means of transport, concepts of transport and cargo handling, or urban space management, which are all aimed at meeting the growing market needs while at the same time mitigating the adverse environmental impacts of the transport system. Implementation of the solutions is aimed at optimising the functioning UFT and its evolution towards Sustainable Urban Freight Transport (SUFT). The sequence of issues addressed in the literature review is shown in Figure 1.

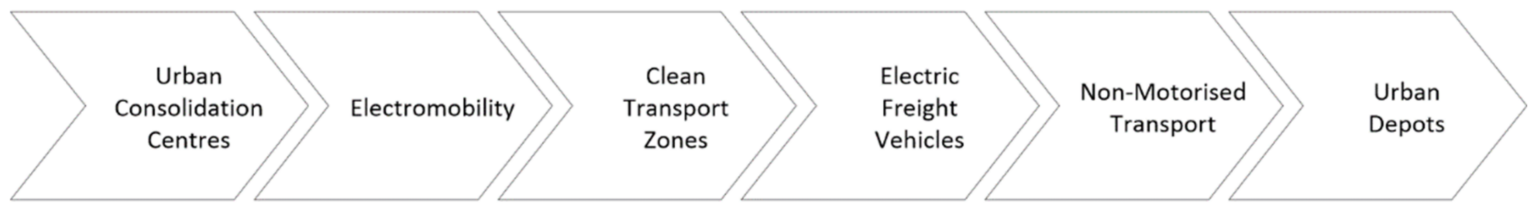

Figure 1. Issues addressed in the literature review.

A significant element of cargo flows in SUFT is the functioning of Urban Consolidation Centres (UCCs) within large cities. Reviewing the literature in that respect, it is also possible to encounter other terms used to denote such facilities: Jacyna [40] describes Cargo Consolidation Centres (CCCs), Malhene et al. [41] and Olsson et al. [42] use the term Freight Consolidation Centres (FCCs), Triantafyllou et al. [43] and Zhou et al. [44] distinguish Urban Freight Consolidation Centres (UFCCs), whereas Oliveira et al. [45], and Agrebi et al. [46] and Sopha et al. [47] highlight Urban Distribution Centres (UDCs). Due to the multitude of names used in the literature to refer to such centres, further on in this article the authors use one term-Urban Consolidation Centre (UCC).

According to van Rooijen et al. [48] and Handoko et al. [49], UCCs are facilities whose task is to combine the dispersed cargo flows coming into the city from the outside into consolidated flows to be delivered as part of last-mile delivery service. UCCs are usually located in the suburban areas of large cities at a relatively small distance from the areas served-the city centre or a specific location (e.g., a shopping mall) [50]. As development of UCCs is aimed at mitigating adverse environmental and social effects ensuing from urban freight transport functioning [51,52], the expected and desired outcomes of implementing such facilities include:

- $\quad$ Reduction in greenhouse gases emissions and in local air pollution [53];

- Reduction in road congestion and problems related to large vehicle traffic in narrow city centre streets [54];

- Improved road traffic safety.

Interesting research studies regarding possibilities of UCCs application in concrete locations were presented by, i.a., Paddeu [55] — for Bristol, England; van Rooijen et al. [48]for Nijmegen, the Netherlands; van Duin et al. [56] — for The Hague, the Netherlands; van Heeswijk et al. [57] for Copenhagen, Denmark; and Correia et al. [58] for Belo Horizonte, Brazil.

The study done by Firdausiyah et al. [59] shows interesting results regarding a potential reduction in emissions as a result of implementation of UCC, whereas Roca-Riu et al. [60] analysed the possibility of obtaining logistic costs savings ensuing from UCC implementation. It is also worth noting the research study completed by Wagner et al. [61], which focused on construction of a special UCC concentrated exclusively on deliveries made to municipal entities in the town of Stargard, Poland-Urban Consolidation Centre for Municipal Entities (UCC-ME). 
In the aspect of developing urban cargo flows in compliance with the SUFT assumptions, electromobility tools have been gaining increasing importance. At this point, it should be noted that the very idea of using electric vehicles in transport is far from new. They have been applied in both passenger and freight transport for many decades. These include passenger and freight trains as well as trams [62,63], also including cargo trams [64,65] and trolleybuses that are still common in many cities. The role of the latter in electromobility development is described in the vast research study completed by Barłomiejczyk et al. [66,67], Wołek et al. [68], and Połom [69].

According to Borowska-Stefańska et al. [70] electromobility may be described in two dimensions: the first pertains to utilisation of electric vehicles (EVs), whereas the second concerns the necessary infrastructure dedicated to the vehicle group. Analysing this definition, it is also worth noting the spatial aspect of electromobility observed in the form of establishing specific city areas accessible only to EVs. A very broad definition of electromobility was proposed by Macioszek [71], according to whom electromobility is the totality of issues connected with the use of EVs, covering, i.a., technical aspects of vehicles, charging technology, and infrastructure, together with social, economic, and legal issues connected with the whole life cycle of EVs. Sierpiński et al. [72], in turn, analyse the concept of electromobility in urban logistics in terms of numerous challenges to its implementation, whereas Škrabul'áková et al. [73] examined the process of preparations made by selected European countries for widespread use of EVs.

The increasingly more commonly applied solution aimed at reducing the traffic in city centres is establishing special zones that may be entered only by specific groups of vehicles. The dynamic growth of electromobility has considerably extended the possibilities. In addition to zones established to prevent entrance of vehicles of specified sizes or zones with traffic speed limitations, other kinds of zones have also been established. Low Emission Zones (LEZs) and Zero Emission Zones (ZEZs) may only be entered by vehicles with reduced environmental impacts. Effectiveness of LEZs and ZEZs in terms of air quality improvement in the city was researched by, i.a., Holman et al. [74], Zhai et al. [75], Tretvik et al. [76], Morfeld et al. [77], Peters et al. [78], and de Bok et al. [79].

In the context of the research study described in this paper, it is necessary to outline the legal regulations pertaining to establishing and functioning of such zones in Poland. The Act of 11 January 2018 on Electromobility and Alternative Fuels (AEAF) adopted by the Polish Parliament [80] imposes on Polish cities a duty to establish zones referred to as Clean Transport Zones (CTZs). Pursuant to the Act, CTZs are established in order to prevent adverse impacts of transport on human health and the natural environment. The duty to establish such zones is imposed on municipalities with populations exceeding 100,000 , and pertains to inner city built-up areas or parts thereof.

Establishing LEZs and ZEZs in a city entails the need to restructure the UFT hitherto functioning in the city. This mainly concerns the need for the operators to replace some of the diesel-powered Light Commercial Vehicles (LCVs) with a carrying capacity of up to $1.5 \mathrm{t}$ with similar, electrically-driven vehicles-Electric Freight Vehicles (EFVs). The utilisation of such vehicles in making deliveries in urban areas was researched by Quak et al. [81], Dong et al. [82], Szczepański [83], and İmre et al. [84]. However, it should be stressed that EFVs mitigate only some of the problems ensuing from cargo-flow handling by means of road transport. Their application decreases emissions of harmful substances and noise, but it does not reduce the number of vehicles in the city centre (the problem of congestion), or the safety of pedestrians and cyclists. Due to their dimensions, EFVs may also be prevented from access to the city areas that allow only small-sized vehicle traffic.

In view of the above, a system of zero-emission last-mile deliveries may be supported also by means of other, smaller vehicles, referred to alternatively as Small Sized Electric Vehicles (SEVs) or Light Electric Freight Vehicles (LEFVs). As shown by Melo et al. [85], SEVs are vehicles characterised by smaller dimensions compared to conventional commercial vehicles, therefore they take up less space, also during unloading operations. In turn, Moolenburgh et al. [86] described LEFVs as quiet, agile, and emission-free vehicles that 
take up less urban space compared to conventional vans and trucks. They also described three basic groups of vehicles categorised as LEFVs: small electric distribution vehicle, electric cargo bike, and electric cargo moped. What is important from the point of view of zero-emission last-mile delivery management, each of the types shows much smaller loading capacity than conventional diesel-powered LCVs or electrically-driven LCVs. Significant limitations of LEFVs, such as small travel range and low speed, are indicated, i.a., by Balm et al. [87].

Many researchers also indicate significant problems with electromobility development. Skrúcaný et al. [88] point out the diverse scope of effects of electromobility implementation in various countries, which depends, i.a., the share of Renewable Energy Sources (RES) in the total electric power production. In their research studies, Csiszár et al. [89] indicated the limited travel range of electric vehicles and the small number of public charging stations. Macioszek [71] also takes note of the longer charging time of EV batteries compared to fuel tanking in the case of conventional vehicles.

In view of the indicated limitations and problems with electromobility development, it is important that in the process of serving any LEZs and ZEZs, EFVs and LEFVs should be supplemented with vehicles from the Nonmotorized Transport (NMT) group. This group includes:

- Cargo bikes/cargo cycles, including, i.a., post bike, bakers' bike, longtail, front- and rear loader-described in more detail by, i.a., Naumov et al. [90], Vasiutina et al. [91], Balm et al. [92], and Dybdalen et al. [93];

- $\quad$ Cycle rickshaws or handcarts-described in more detail by Gupta [94];

Similarly, as in the case of LEFVs, NMT are also characterised by limited travel range and carrying capacity.

The limited travel range and carrying capacity of LEFVs and NMT may lead to a need to intervene in the hitherto last-mile delivery system. The distance between an UCC and end customers may be too long for LEFVs and NMT to be used on the whole route, or it may turn out to be unreasonable in technical, economic, or organisational terms. In this case, there is a possibility of organising a two-level distribution system and providing it with additional, small transshipment points in the direct vicinity of LEZs or ZEZs. The available literature features numerous terms applied to describe such points. Elbert et al. [95] referred to them as Micro Depots (MDs) and Micro Consolidation Centres (MCCs); Elhaq et al. [96] used the term, Proximity Logistics Spaces (PLSs); Montwiłł et al. [97] named them Urban Depots (UDs), while Bosona [98] wrote about Local Distribution Centres (LDCs). Due to the multitude of names used in the literature to refer to such transshipment points, further on in this article the authors use one term-Urban Depot (UD).

What is important from the point of view of this article, according to Enthoven et al. [99] and Hof et al. [100], is an alternative approach to last-mile deliveries by using additional intermediate points on the route between UCC and end customer, which makes it possible to transship goods from conventional LCVs to zero-emission vehicles that are suitable for traffic and deliveries in densely populated areas characterised by narrow streets.

Summarising, the literature addresses a very broad range of issues related to how urban delivery systems function, and describes various solutions. Unfortunately, it should be noted that the issue of applying rail transport in urban delivery system has been analysed to a very limited extent; in this context it is worth mentioning papers published by, i.a., Gonzalez-Feliu [101], Diziain et al. [102], and Kelly et al. [103].

Paradoxically, most of the solutions proposed in the literature, which are aimed at mitigating adverse effects of transport in cities, pertain to road transport. It is quite puzzling in view of the fact that transport problems faced by cities are predominantly due to the excessive and uncontrolled use of that mode of transport. Measures implemented as part of electromobility programmes, which consist in gradual replacement of internal combustion vehicles with their electric counterparts, unfortunately solve only some of the transport-related problems encountered by cities. Although EVs do reduce emissions of 
pollutants and noise, they do not decrease traffic congestion, the number of road accidents, land consumption, or land-use change.

Therefore, this article addresses the identified literature gap in the area of applying rail transport in an urban delivery system. Our research results demonstrate the effects of incorporating LFR electric trains into the ZUDS, using the example of the city of Szczecin, Poland.

\section{Study Stages and Input Data}

The article presents research on the effects of incorporating rail transport into the ZUDS. The study was based on the example of the city of Szczecin, Poland. The research process was divided into six stages, which are outlined in Figure 2:

- Stage 1: literature review concerning the technical and organisational changes taking place in UFT, leading to identifying the literature gap, research goal, and research questions;

- Stage 2: analysis of the current state, i.e., the research area being the city of Szczecin, and the present urban delivery system were characterised;

- $\quad$ Stage 3: defining the assumptions for studying effects of incorporating rail transport into the ZUDS;

- $\quad$ Stage 4: estimation of transport external costs resulting from shifting urban deliveries from road to rail transport for the city of Szczecin example, taking into account application of the LFR system developed by the authors in their earlier research studies;

- $\quad$ Stage 5: identification of other effects resulting from shifting urban deliveries from road to rail transport on the city of Szczecin example, taking into account application of the LFR system;

- The last stage of the research study was the discussion of the results and formulation of the conclusions.

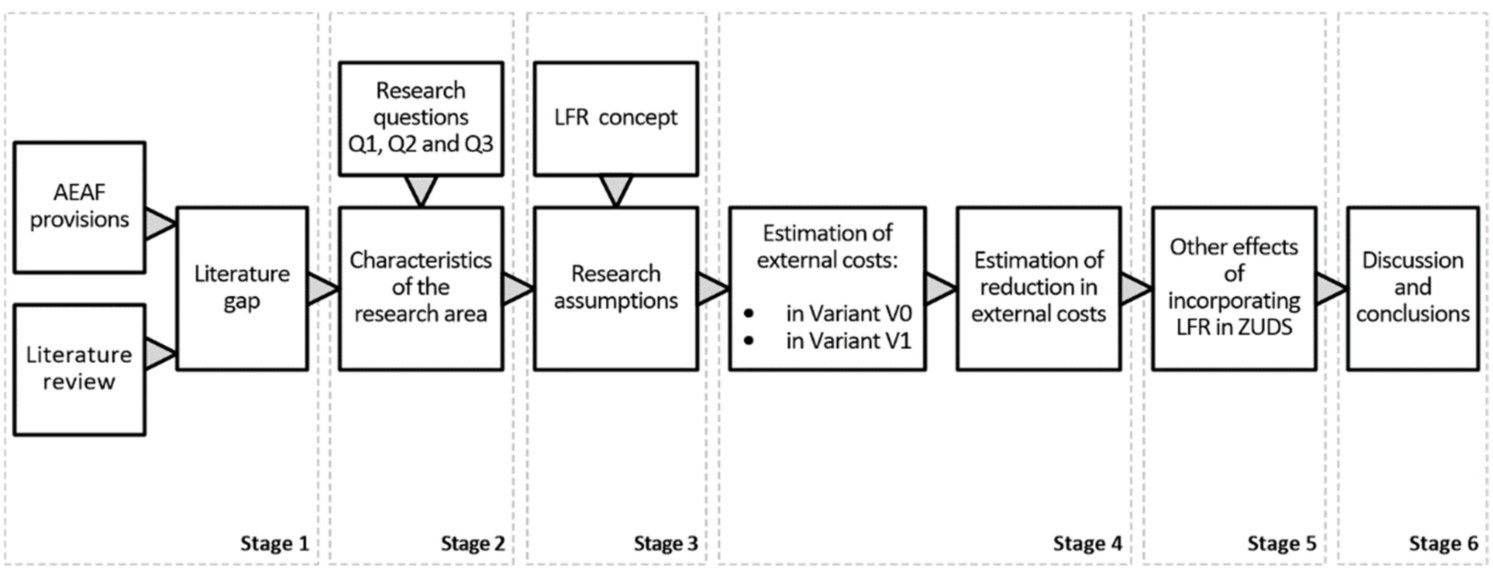

Figure 2. The research process flow diagram.

The following input data were used for the purposes of the research study:

- Statistical data regarding the research area, i.e., the city of Szczecin;

- Provisions of the Act of 11 January 2018 on Electromobility and Alternative Fuels (AEAF) [80];

- The assumptions regarding the original LFR system developed by the authors-its functioning scheme is outlined in their earlier publications [97,104-106];

- Average costs per category for individual means of transport, as per the Handbook on the External Costs of Transport, Version 2019, developed by the European Commission [107]. 


\section{Characteristics of the Research Area}

The research area covered by the case study was the city of Szczecin, located in northwest of Poland. The city is situated on the Oder River and Dabie lake, in the vicinity of Poland's land and sea frontiers, at the distance of ca. $65 \mathrm{~km}$ from the Baltic Sea coastline, ca. $130 \mathrm{~km}$ from Berlin, ca. $274 \mathrm{~km}$ from Copenhagen, ca. $454 \mathrm{~km}$ from Stockholm, ca. $507 \mathrm{~km}$ from Prague, and ca. $516 \mathrm{~km}$ from Warsaw. Szczecin is the capital and largest city in the West Pomerania Voivodeship, both in terms of the surface area and the population. According to the statistical data as of 30 June 2020, Szczecin covers an area of $301 \mathrm{~km}^{2}$, and its population is 400,990 [108]. The city is also the centre of the Szczecin Metropolitan Area (SMA).

From the point of view of the adopted research goal, the relevant aspects that characterise the research area are the spatial layout of the city, the transport infrastructure providing transport accessibility to and within the city limits, and the current urban delivery system.

The spatial layout of the city is quite peculiar-it is dipolar. This is due to the fact that the city is situated at the Oder River estuary and its flood plains, and that the seaport is also located in this area (Miedzyodrze). Consequently, the city area is naturally divided into two parts: the left-bank (Lewobrzeże) and the right-bank (Prawobrzeże), which has shaped their functionalities.

The left-bank part of Szczecin is dominated by services at the municipal, regional, national, and international level, whereas the right-bank part of the city features the city centre that serves the local and suburban purposes, focusing on the direct vicinity of the city [109]. The analysis of the functional system of the city indicates that in the left-bank part of Szczecin, the dominating functions are services, administration, education, culture, sport, entertainment, tourism, and hotels, whereas in the right-bank part the prevailing functions are production, warehousing, and storage. This functional division makes the left-bank part of the city representative and important to its residents and visitors.

Additionally, both parts of the city are separated by the area of Miedzyodrze with a concentration of production and service facilities connected with the functioning of the seaport and shipbuilding industry. This area is specific due to the fact that it is ca. $8 \mathrm{~km}$ wide and it is excluded from other city-related functions.

It is also important to note that the residential function is found in both-the left-bank and the right-bank parts of the city, except for the Miedzyodrze area. It should also be noted that in Szczecin, similarly as in other cities in Poland and Europe, we observe the diminishing residential function in the city centre and suburbanisation of the outskirts. This is mainly connected with the migration of residents to the newly built housing estates located out of the city centre, or the migration out of the city to the rural areas.

In the aspect of (both passenger and freight) transport planning and organisation in the city, another important factor to consider is the fact that the city centre in Szczecin is used for transit purposes. The city centre serves as the interchange point for residents who wish to move between the individual districts of the city. This means that a considerable number of the residents arrive daily to this part of the city on their way to work, school, or administration centres.

Implementation of an urban delivery system to a large extent depends on the available transport infrastructure. The following traffic routes run through the city of Szczecin:

- $\quad$ Road transport: A6 motorway linking Szczecin with the country border and farther on with Berlin, expressways: S3 (E65), S6, S10, and S11 linking Szczecin with other major cities in Poland;

- Rail transport: railways: 273, 351, and 401, being part of E59 and CE59 European transport routes;

- Inland transport: inland routes linking Szczecin via the Oder River with the port of Świnoujście, and via the Oder-Havel Canal with Berlin

- Seaborne transport: Szczecin seaport has connections with other European seaports. 
The last major element characterising the research area in relation to the adopted research goal is the current urban delivery system. It should be noted that as opposed to the passenger transport, urban freight transport in Poland is not governed by national legal regulations pertaining to its organisation by local self-government. Similarly, as in the case of other Polish cities, freight transport in Szczecin is handled by numerous dispersed entities characterised by diverse operations profiles, structures, and sizes or functioning ranges.

There are two kinds of freight deliveries in the area of Szczecin. The first kind pertains to cargo destined for the seaport. Overland deliveries are made via rail haulage, and large goods vehicles made up of truck tractors and semi-trailers. The second kind of deliveries covers those of dispersed nature, made within the city area and destined for end customers or pick-up points. They are made only with road vehicles, predominantly by means of diesel-powered LCVs. As opposed to the public passenger transport, in Szczecin currently there are no implemented solutions regarding freight transport, which would correspond to electromobility assumptions and goals.

\section{Characteristics of the Light Freight Railway Concept}

In the aspect of urban deliveries, rail transport offers many features that can be decisive for its competitiveness in relation to other modes of transport. These include, i.a., considerable speed, high level of safety, considerable carrying capacity, no dependency on weather conditions, low impact on the natural environment, and independence from road traffic congestion. These features indicate a significant potential held by this mode of transport in terms of deliveries made in compliance with the SUFT assumptions. However, in business practice, making use of rail transport in freight deliveries is to a significant extent determined by the quantitative and qualitative status of the infrastructure, i.a., the number of available railway sidings or the length of a conventional train composed of an engine and a dozen or several dozen wagons. A small number of railway sidings in a given area limits the possibility of making direct "door-to-door" rail deliveries, and necessitates incorporation of other modes of transport (usually road transport) into the transport process. During transshipment, a traditional train composed of a locomotive and a dozen or several dozen wagons requires a railway siding of an appropriate length, which will make it possible to handle the whole train at the same time. A constraint in rail transport utilisation may also be the need for complicated and time-consuming manoeuvres at railway sidings, which require decoupling and shunting of wagons and moving the engine from one end of the train to the other. To this end, the use of an additional manoeuvre locomotive might also be required.

The analysis of the constraints related to utilisation of rail transport in urban deliveries handling indicates that it is necessary to develop innovative means of rail transport, which also implies modern forms of their handling.

The study of effects of incorporating rail transport into the ZUDS in Szczecin was conducted with the use of the original concept, i.e., Light Freight Railway (LFR). LFR applies small, bidirectional Freight Multiple Units (FMU) operating without a separate locomotive. FMU is composed of several (minimum two) wagons, where the outermost wagons of a train are equipped with driver's cabins. Owing to this, a LFR train may be handled:

- Within a railway network dedicated to passenger traffic, e.g., on urban and agglomeration lines;

- Directly at railway stations;

- On railway sidings with limited lengths, located within a city.

Due to the small length of LFR trains, transshipment operations performed within railway sidings may be considerably simplified, as there is no need to shunt any individual wagons. Moreover, due to providing the two outermost wagons with driver's cabins, the train is bidirectional. The railway siding may be entered and exited in the push-pull system 
(Figure 3), without the need for moving the engine from one end of the train to the other or engaging an additional manoeuvre locomotive.

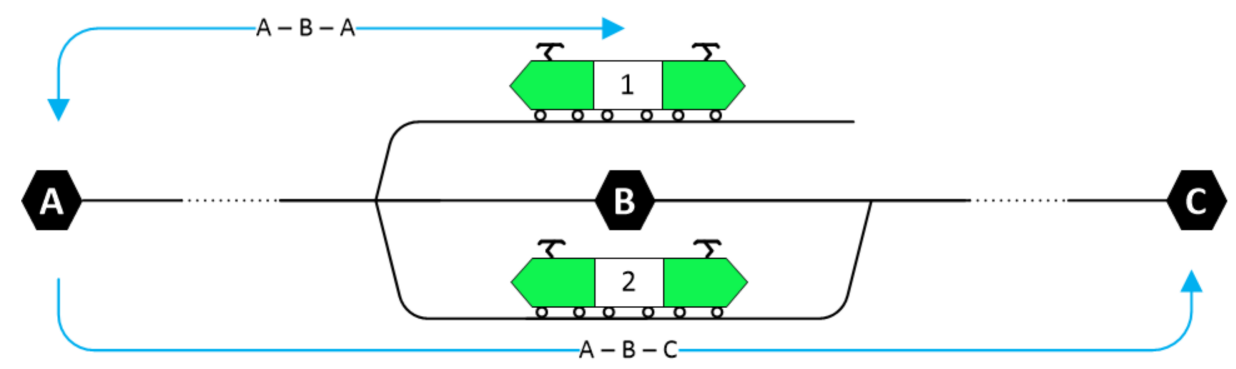

LEGEND:

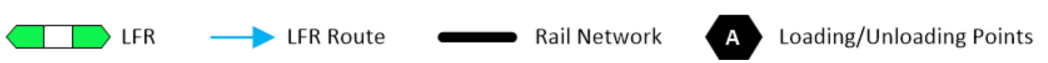

Figure 3. LFR train operation system.

It should be noted that LFR trains may be powered in different ways depending on the available infrastructure and needs. What is important from the point of view of the research study described in this paper, in addition to internal combustion engine, LFR trains may be powered by electric traction networks or use hybrid solutions, thus their application may constitute an important element of SUFT and support electromobility development in cities. In view of the research goal, to estimate the effects of incorporating rail transport into the ZUDS in Szczecin, it was assumed that the LFR trains are electrically powered.

\section{Study of Effects of Incorporating Rail Transport into the Zero-Emission Urban Deliveries System-Case Study of the City of Szczecin, Poland}

\subsection{Research Assumptions}

As already mentioned in Chapter 4, in the current urban delivery system in Szczecin individual operators make deliveries from their logistic centres located usually on the city outskirts or even outside its borders, directly to end customers or pick-up points dispersed across the whole city. The deliveries are made predominantly by means of diesel-powered LCVs.

It should be noted that as a result of the provisions of AEAF, it will be necessary to significantly modify this system in selected parts of the city. Even though AEAF does not specify the principles of urban delivery system functioning, it does stipulate the obligation to establish CTZs by city authorities, which will lead to the need to introduce numerous changes regarding cargo flow handling in such zones. One of them will be replacing some of the vehicles in the fleet with zero-emission ones. However, it should be noted that replacement of traditional diesel-powered LCVs with similar but electrically driven vehicles will not solve all the problems related to freight traffic in CTZs. Admittedly, the process will make it possible to reduce the pollution and noise levels; however, it will not reduce the traffic congestion and it will not increase the safety of pedestrians and cyclists.

Analysing the possible solutions concerning future delivery handling in Szczecin, it must not be forgotten that most of the left-bank part of the city shows historic, tourist, and representative values. It is predominantly a densely built-up area, which means there is only limited space for vehicle traffic or safe parking, or for establishing loading/unloading bays. Making deliveries in such areas by means of LCVs of any kind, regardless of their drive, significantly constrains the urban space functionality and free movement of pedestrians and cyclists, at the same time leading to degradation of the infrastructure and urban greenery.

What is important, as a result of increased road traffic in the centre of Szczecin, is that the city authorities have already started the process of modifying some of the streets in the inner city by establishing "30 km/h zones". As part of these measures, changes are introduced to the hitherto road traffic organisation. In such zones, in addition to the considerable reduction in permissible speed for road vehicles, some traffic lanes are 
eliminated, right-of-way intersections are replaced with all-way-stop intersections, oneway street routes are established, and some streets are excluded from vehicle traffic. At the same time, such zones favour pedestrian and cycling traffic, cycle paths are built, contraflow lanes for bicycles are organised within one-way roads, pedestrian crossings are widened and their number increased. All these measures are aimed at elimination of transit traffic from the city centre, as well as traffic calming and increased safety of pedestrians and cyclists.

In view of the measures currently taken by the city authorities to regulate and reduce road traffic in the city centre, and also in view of the AEAF provisions concerning the need to establish CTZs, it should be noted that it will be problematic to use LCVs to handle cargo flows in CTZs - the use of diesel-powered LCVs will be impossible due to their emissions, whereas the use of electric LCVs will be constrained due to the size of the vehicles. A solution that makes it possible to handle last-mile deliveries in CTZs, using the infrastructure that is inaccessible for electric LCVs, is application of LEFVs and NMT. Due to their zero-emission feature and small dimensions, they are able to reach end customers or pick-up points located in CTZs.

However, while organising last-mile deliveries with the use of LEFVs and NMT, it is also necessary to take into account the specific nature of these vehicles. Due to their limited travel range and small carrying capacity, it is impossible for them to be loaded, similarly as in the case of LCVs, in logistic centres and warehouse located on the outskirts or outside the city limits. Therefore, it is necessary to organise, in the direct vicinity of CTZs, mobile or nonmobile UDs where cargo brought from areas outside the city centre can be transshipped onto vehicles eligible to enter the CTZs.

This research study on effects of incorporating rail transport into the ZUDS in Szczecin takes into account the conditions noted above.

The following assumptions were adopted in connection with the research study:

1. CTZs will be established in the city centre, pursuant to the provisions of AEAF.

2. Last-mile deliveries in the CTZs in Szczecin will be made exclusively by means of vehicles eligible to enter CTZs: LEFVs and NMT vehicles.

3. Due to the limitations of LEFVs and NMT (limited carrying capacity and travel range, time-consuming battery charging), Urban Depots will be established around the Clean.Transport Zones. In the UDs, the following operations will be performed:

- Transshipment from the vehicles bringing cargo from the areas outside the city centre onto the vehicles eligible to enter CTZs;

- Charging the EVs;

- Possibly short-term storage.

4. UDs will be established in the following locations (all in the left-bank part of the city):

- UD Gumieńce-located directly next to the "Szczecin Gumieńce" railway station, which has appropriate land reserves. In the vicinity of this place there are densely built-up housing estates, commercial zones (large-format retail outlets, wholesale outlets), a university campus, and a fast developing suburban residential zone (multi- and single-family houses).

- UD Turzyn-located directly next to the "Szczecin Turzyn" railway station, which has appropriate land reserves. In the vicinity of this place there are densely built-up housing estates, commercial zones (large-format retail outlets), a university campus, and hospitals.

- UD Niebuszewo-located directly next to the "Szczecin Niebuszewo" railway station, which has appropriate land reserves. In the vicinity of this place there are densely built-up housing estates, commercial zones (large-format retail outlets), a university campus, hospitals, and production zones.

5. Due to the diverse locations of logistic centres and warehouses currently used in making urban deliveries in the city of Szczecin, it is suggested to establish one UCC to be shared by all the operators. The choice of the UCC was in particular dependent on: 
- Location outside the core city centre-as per van Rooijen et al. [48];

- Access to national and international roads and railway lines;

- Access to urban roads and railway lines;

- Access to land reserves.

In view this, the suggested location of the UCC to handle urban deliveries in Szczecin is in the right-bank part of the city (marked on Figure 4 as "UCC Dunikowo"). The location is equipped with a railway siding and it is situated directly next to railway lines 351 and 401, as well as next to the current and planned expressways-S3, A6, and S10. It should also be stressed that in the future an intermodal terminal is planned to be built there.

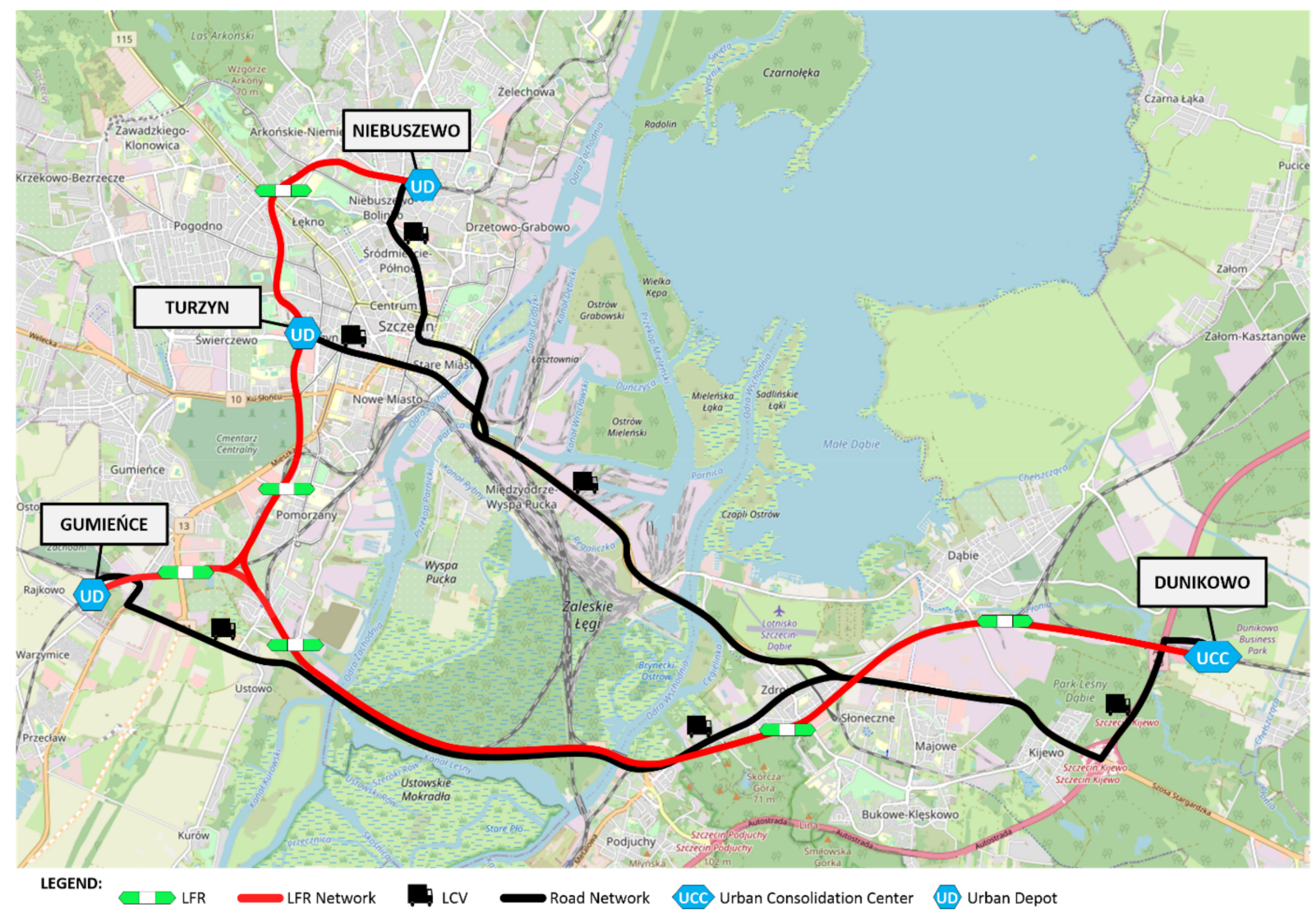

Figure 4. Routes that are part of variant V0 and variant V1.

For the research purposes, two variants of urban delivery system functioning were adopted for Szczecin: V0 (minimum) and V1 (extended). Both variants take into account the need for the city authorities to establish CTZs pursuant to the provisions of AEAF.

Variant V0 (minimum) assumes that cargo will be delivered from the UCC to UDs located in the centre of Szczecin by means of diesel-powered LCVs. Then, in accordance with the adopted assumptions, in the local UDs cargo will be transshipped onto vehicles eligible to enter CTZs, which will then make zero-emission last-mile deliveries. In this way, variant V0 reflects the current urban delivery system in Szczecin, only taking into account the need imposed by AEAF to establish CTZs, and thus it merely ensures zero-emission last-mile deliveries in that area.

Variant V1 (extended) assumes deliveries of cargo from the UCC to UDs located in the centre of Szczecin via rail transport by means of applying the original, zero-emission LFR system. Thus, this variant assumes extension of the zero-emission delivery system also beyond last-mile deliveries. Last-mile delivery handling from the individual UDs in variant $\mathrm{V} 1$ is the same as in the case of variant $\mathrm{V} 0$. 
The graphic presentation of variants V0 and V1 can be seen in Figure 4. The black line represents the route to be covered by diesel-powered LCVs in variant V0, the red line marks the route to be covered by LFR electric trains in variant V1.

For the purposes of calculations pertaining to variants V0 and V1, the carrying capacity of the vehicles and lengths of the individual routes were estimated. In the case of variant $\mathrm{V} 0$ it was assumed that the carrying capacity of each LCV amounts to 1.5 tonnes. On that basis it was further assumed that one LCV would serve one UD at a time. The routes of the individual LCVs were specified as follows:

- UCC-UD Gumieńce-UCC: $20.7 \mathrm{~km} \times 2=41.4 \mathrm{~km}$;

- UCC-UD Turzyn-UCC: $20.0 \mathrm{~km} \times 2=40.0 \mathrm{~km}$;

- $\quad$ UCC-UD Niebuszewo-UCC: $19.7 \mathrm{~km} \times 2=39.4 \mathrm{~km}$.

In the case of variant $\mathrm{V} 1$, it was assumed that the carrying capacity of each LFR train amounts to 45 tonnes. A train consists of two wagons equipped with driver's cabins, with a carrying capacity of 14 tonnes each, and one middle wagon with a carrying capacity of 17 tonnes. Therefore, it is possible and reasonable that one LFR train can serve all the three UDs at a time. The LFR train route was specified as follows:

- UCC Dunikowo-UD Gumieńce-UD Turzyn-UD Niebuszewo-UCC Dunikowo: $50.7 \mathrm{~km}$.

The entire analysed railway route is provided with electric traction, which makes it possible to use LFR electric trains on it.

In accordance with the adopted research methodology, the computations do not include last-mile deliveries to be made from the individual UDs to end customers. This is because the last-mile deliveries are to be made in the same way in both variantsexclusively by means of vehicles that are eligible to enter the CTZs in the city; therefore, the last-mile deliveries are not analysed in this paper.

6.2. Study of the Transport External Costs Resulting from Shifting Urban Deliveries from Road to Rail Transport in the City of Szczecin

In order to study the effects of incorporating rail transport into the ZUDS, it was necessary to estimate the external costs of transport resulting from shifting urban deliveries from road to rail transport. The estimation was based on the example of the Szczecin city, taking into account two variants of urban delivery system functioning adopted for the study: variant V0 (minimum) assuming cargo deliveries with vehicles categorised as Light Commercial Vehicle Category N1 (LCV) [110] and variant V1 (extended) assuming deliveries with LFR electric trains.

Estimation of the effects was based on the EU methodology regarding the amount of external costs generated by specific means of transport used in the individual modes of transport [107]. The computations take into account the average costs per category for individual means of transport, as per the Handbook on the external costs of transport, Version 2019, [107]. The computation of a reduction in external costs was performed per one Delivery Cycle (DC), covering transport of cargo from the UCC to all the three UDs. Considering the maximum carrying capacity of a LFR train, it was assumed that 1 DC involves transport of a cargo totalling 45 tonnes, out of which 15 tonnes are delivered to UD Gumieńce, 15 tonnes are delivered to UD Turzyn, and 15 tonnes are delivered to UD Niebuszewo.

Estimation of External Costs in Variant V0

In order to calculate the external costs generated by the means of transport in variant $\mathrm{V} 0$, the following data were adopted:

- Deliveries from UCC to UDs are made by means of diesel-powered LCVs;

- $\quad$ Carrying capacity of $1 \mathrm{LCV}=1.5$ tonnes;

- $\quad$ One DC (45 t) is handled by 30 LCVs (10 vehicles per each UD);

- Average external cost per diesel-powered LCV=0.247 EUR/vkm. 
Assuming the EU methodology concerning external costs generated by the means of road transport, [107] the following formula was applied for the computation:

$$
\mathbf{E C}_{\mathrm{V} 0}=\mathbf{W}_{\mathrm{LCV}} *\left(\mathbf{D}_{\mathrm{LCV}-\mathrm{G}} * \mathbf{N}_{\mathrm{LCV}-\mathrm{G}}+\mathbf{D}_{\mathrm{LCV}-\mathrm{T}} * \mathbf{N}_{\mathrm{LCV}-\mathrm{T}}+\mathbf{D}_{\mathrm{LCV}-\mathrm{N}} * \mathbf{N}_{\mathrm{LCV}-\mathrm{N}}\right) * \mathbf{U E C} \mathrm{VO}_{\mathrm{VO}}
$$

where:

$\mathrm{EC}_{\mathrm{V} 0}$ - external costs generated by LCVs per 1 DC (EUR);

$\mathbf{W}_{\mathrm{LCV}}$ - cargo weight per $1 \mathrm{LCV}$ (tonnes);

$\mathrm{D}_{\mathrm{LCV}-\mathrm{G}}$ - distance covered from UCC to UD Gumieńce and back to UCC $(\mathrm{km})$;

$\mathbf{N}_{\mathrm{LCV}-\mathrm{G}}$-number of LCVs bringing cargo to UD Gumieńce per 1 DC (pcs);

$\mathbf{D}_{\mathrm{LCV}-\mathrm{T}}$ - distance covered from UCC to UD Turzyn and back to UCC $(\mathrm{km})$;

$\mathbf{N}_{\mathrm{LCV}-\mathrm{T}}$-number of LCVs bringing cargo to UD Turzyn per 1 DC (pcs);

$\mathbf{D}_{\mathrm{LCV}-\mathrm{N}}$ - distance covered from UCC to UD Niebuszewo and back to UCC $(\mathrm{km})$;

$\mathbf{N}_{\mathrm{LCV}-\mathrm{N}}$-number of LCVs bringing cargo to UD Niebuszewo per 1 DC (pcs);

UEC $_{\mathrm{VO}}$ - external unit costs generated by $1 \mathrm{LCV}$ at a distance of $1 \mathrm{~km}$ (EUR).

External costs generated by LCVs per 1 DC in variant V0 for the analysed case study are:

$$
\begin{gathered}
\mathbf{E C}_{\mathrm{V} 0}=1.5 *(41.4 * 10+40.0 * 10+39.4 * 10) * 0.247 \\
\mathbf{E C}_{\mathrm{V} 0}=447.56 \mathrm{EUR}
\end{gathered}
$$

\section{Estimation of External Costs in Variant V1}

In order to calculate the external costs generated by the means of transport in variant $\mathrm{V} 1$, the following data were adopted:

- Deliveries from UCC to UDs are made by means of LFR electric trains;

- $\quad$ Carrying capacity of 1 LFR = 45 tonnes;

- $\quad$ One DC (45 t) is handled by 1 LFR train;

- Average external cost for electric freight railway trains $=0.0112 \mathrm{EUR} / \mathrm{tkm}$.

Assuming the EU methodology concerning external costs generated by the means of rail transport [107], the following formula was applied for the computation:

$$
\mathrm{EC}_{\mathrm{V} 1}=\mathbf{W}_{\mathrm{LFR}} * \mathrm{D}_{\mathrm{LFR}} * \mathrm{UEC}_{\mathrm{V} 1}
$$

where:

EC $_{\mathrm{V} 1}$ - external costs generated by an LFR electric train per 1 DC (EUR);

$\mathbf{W}_{\mathrm{LFR}}$ - cargo weight per 1 LFR train (tonnes);

$\mathrm{D}_{\text {LFR }}$ - delivery distance on the route: UCC Dunikowo-UD Gumieńce-UD TurzynUD Niebuszewo-UCC Dunikowo (km);

UEC $_{\mathrm{V} 1}$ - external unit costs generated by 1 LFR train in transporting 1 tonne at a distance of $1 \mathrm{~km}(\mathrm{EUR} / \mathrm{tkm})$.

External costs generated by LFR per 1 DC in variant V1 for the analysed case study are:

$$
\begin{gathered}
\mathrm{EC}_{\mathrm{V} 1}=45.0 * 50.7 * 0.0112 \\
\mathrm{EC}_{\mathrm{V} 1}=25.55 \mathrm{EUR}
\end{gathered}
$$

To compute the reduction in the external costs per $1 \mathrm{DC}$, being the result of shifting urban deliveries from road (V0) to rail (V1) transport in the city of Szczecin, the following formula was adopted:

$$
\begin{gathered}
\mathbf{R}_{\mathrm{EC}}=\mathbf{E C}_{\mathrm{V} 0}-\mathbf{E C}_{\mathrm{V} 1} \\
\mathbf{R}_{\mathrm{EC}}=447.56 \mathrm{EUR}-25.55 \mathrm{EUR}=422.01 \mathrm{EUR}
\end{gathered}
$$

As results from the above, application of LFR trains in the ZUDS in Szczecin will make it possible to reduce the external costs generated by the means of transport, which provides a positive answer to research question RQ1 posed in the Introduction. In the analysed case study, the reduction in external costs per 1 DC amounts to 422.01 EUR. Assuming that 
during one day only $1 \mathrm{DC}$ is completed, the yearly reduction in external costs will amount to over 154,000 EUR.

In case more DCs are completed per day, the annual reduction in external costs resulting from incorporating LFR into the ZUDS in Szczecin, may amount to:

- $\quad$ For 2 DCs completed per day-308,067.30 EUR;

- For 3 DCs completed per day-462,100.95 EUR;

- For 4 DC s completed per day-616,134.60 EUR.

6.3. Study of Other Effects Resulting from Shifting Urban Deliveries from Road to Rail Transport in the City of Szczecin

Taking into account the results of the computations described in Section 6.2, it is possible to notice that incorporating rail transport (variant V1) into the ZUDS may bring a number of positive effects with regard to reduction in external costs of transport.

In view of the assumed carrying capacity of the LFR train, which corresponds to that of $30 \mathrm{LCVs}$, application of LFR trains may lead to considerable reduction in the number of vehicles on the city roads. Completion of 1 DC on the UCC Dunikowo-UD GumieńceUD Turzyn-UD Niebuszewo-UCC Dunikowo route by means of a LFR train may enable elimination of 30 single deliveries made by LCVs in the city area, covering the total of $1208 \mathrm{~km}$. Within one year, this means a reduction of up to 10,950 deliveries made by LCVs covering the total of $440,920 \mathrm{~km}$.

In case more DCs are completed per day, the annual reduction in the number of deliveries made by LCVs resulting from incorporating LFR into the ZUDS in Szczecin may amount to:

- $\quad$ For 2 DCs per day-21,900 deliveries, total distance of $881,840 \mathrm{~km}$;

- For 3 DCs per day-32,850 deliveries, total distance of $1,322,760 \mathrm{~km}$;

- For 4 DCs per day-43,800 deliveries, total distance covered: 1,763,680 km.

This significant reduction in the number of deliveries made by LCVs driving within the city may have an impact on decreasing the road traffic congestion, decreasing the number of accidents, increasing the road safety, and decreasing the level of road infrastructure degradation. Moreover, a significant reduction in the number of LCVs in the city centre may also have an impact on traffic calming and uncluttering of the urban transport system, thus making it possible to manage the public space in a resident-friendly manner.

Another important issue regarding the effects of incorporating rail transport into the ZUDS is that the way of locating and handling the local UDs is different than the one in the case of applying LCVs.

In the case of using LCVs to make deliveries to UDs (variant V0), it should be borne in mind that these vehicles are not eligible to enter CTZs. Therefore, in order to ensure the possibility of transshipping cargo from LCVs to vehicles capable of making zero-emission last-mile deliveries (LEFVs and NMT), the UDs may only be located outside the CTZs or directly at their borders. Consequently, in the case of implementing variant V0, there is no possibility of locating any UDs inside CTZs. This may have specific implications in the future- the functioning UDs and the road infrastructure used by LCVs to reach the UDs may hinder or even prevent the possibility of extending the CTZs.

In this case, two alternative scenarios of CTZ spatial development are possible:

- Any future spatial development of CTZs will be uneven due to the need to bypass the UDs along with the infrastructure used by LCVs (Scenario A in Figure 5);

- It will be necessary to build a new UD (along with the accompanying infrastructure) outside the extended CTZ so as to enable LCV traffic, which will each time generate additional costs (Scenario B in Figure 5). 
Scenario A
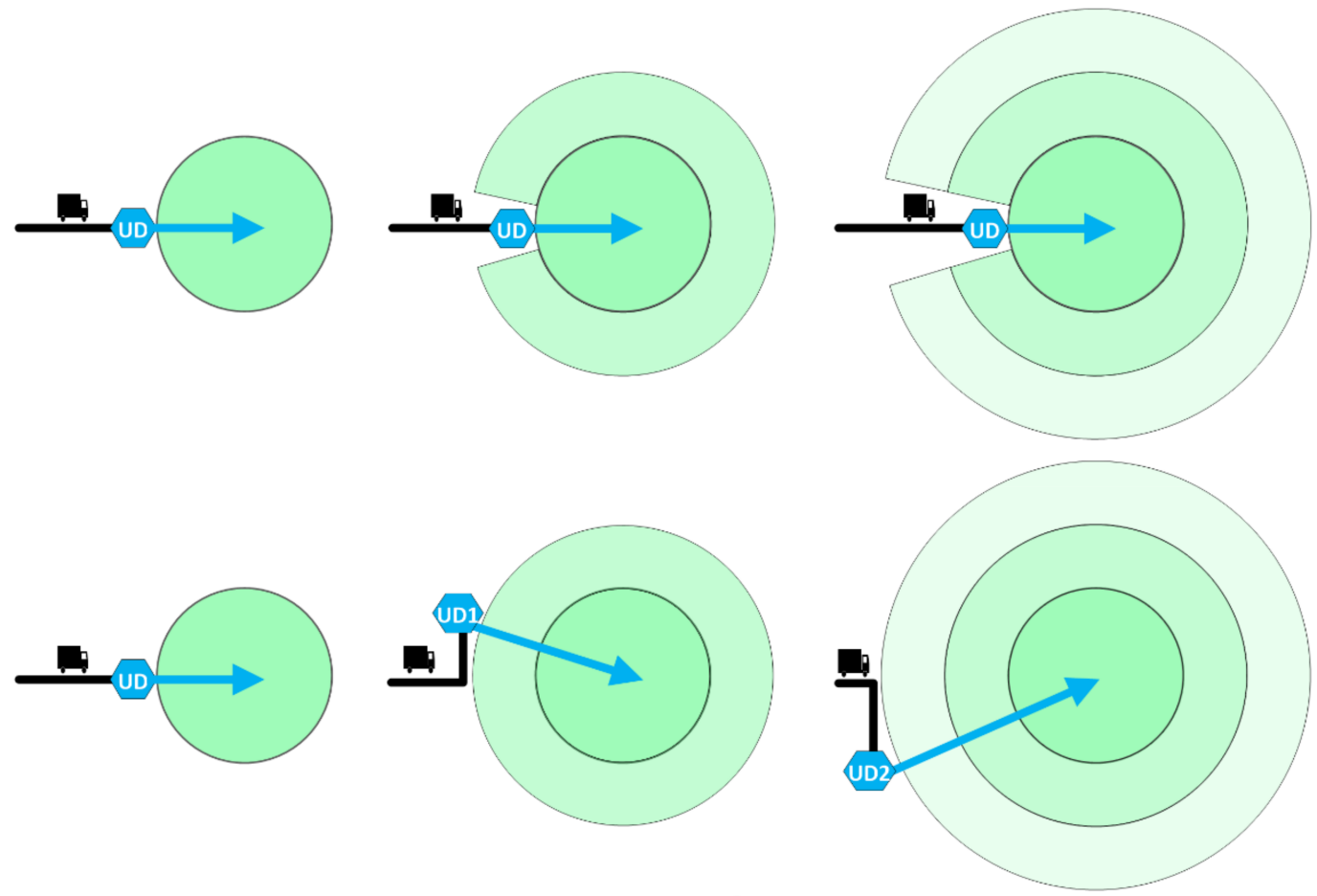

LEGEND:

Figure 5. Scenarios of CTZ spatial expansion in variant V0.

It is worth noting that the CTZ expansion scenarios in variant V0, presented in Figure 5, would be unfavourable for organisational, spatial, and economic reasons.

Delivery-making by means of LFR trains (variant V1) makes it possible for CTZs to expand in the city and for UDs to be located and handled in a way that is different from variant V0. In variant V1 it is possible to locate UDs (along with the railway infrastructure) within the CTZ, because, as opposed to LCVs, LFR electric trains may be part of CTZ traffic. Therefore, UDs that are served by LFR will not hinder the possibility of CTZ spatial expansion. In variant V1, UD may be located within the CTZ; it may even become its central point. In this case, any CTZs may expand evenly in each direction, without the need to bypass any UD or to construct a new UD (along with the accompanying infrastructure) at the individual stages of the CTZ development.

A sample scenario of CTZ expansion in the case LFR is used (variant V1) to make deliveries to UD Turzyn in Szczecin is presented in Figure 6. It was assumed that this zone would be expanded in stages, as follows:

- First stage-within a radius of ca. $1 \mathrm{~km}$ from UD Turzyn;

- $\quad$ Second stage-within a radius of ca. $2 \mathrm{~km}$ from UD Turzyn;

- Third stage-within a radius of ca. $3 \mathrm{~km}$ from UD Turzyn. 


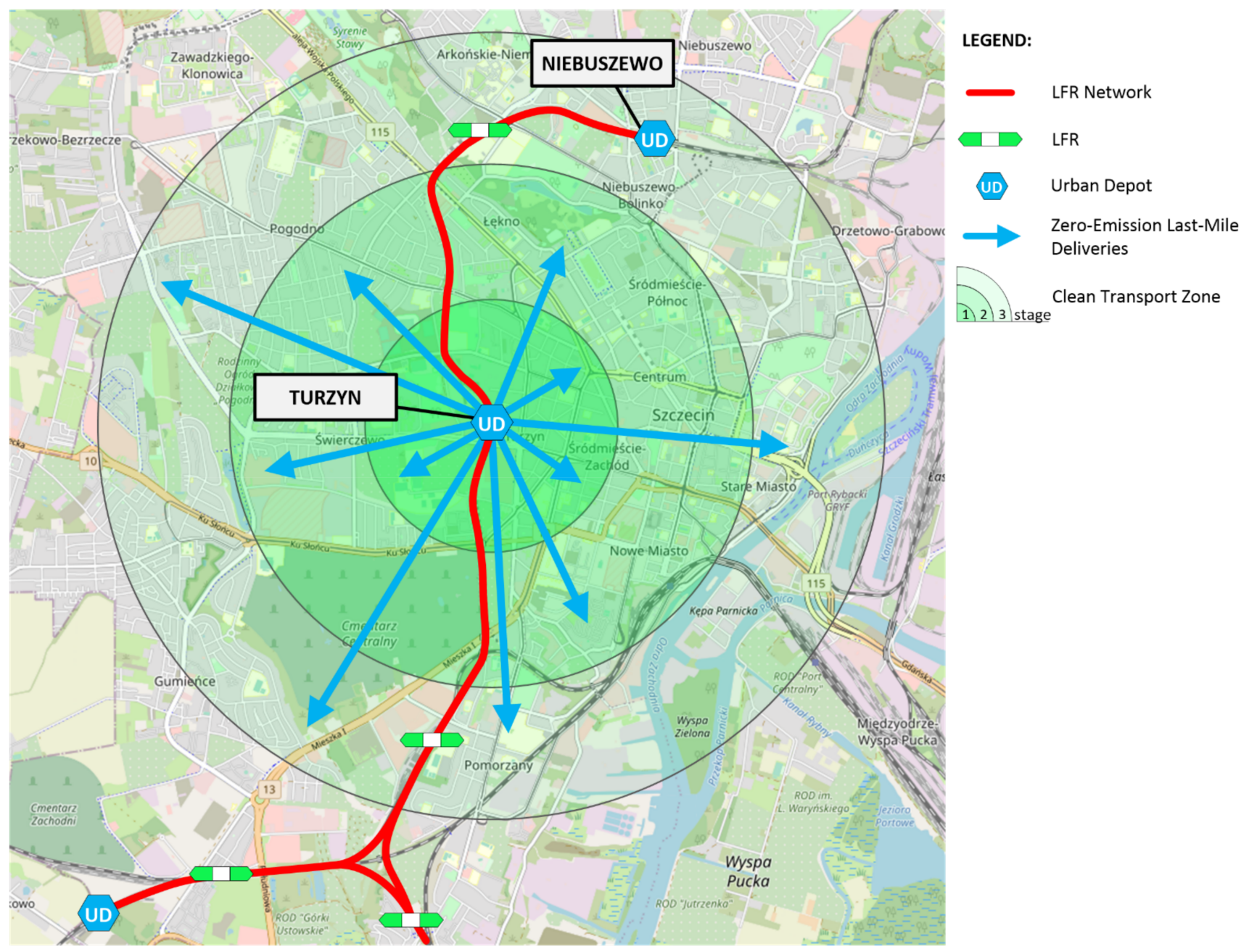

Figure 6. Scenario of CTZ expansion in the case LFR is used (variant V1) to make deliveries to UD Turzyn in Szczecin.

It should be noted that an even expansion of the individual CTZs in the city, being a result of applying LFR (variant V1), also provides a possibility of partial overlapping of those zones at subsequent stages of their development. Consequently, it may be possible to obtain a coherent clean transport zone with a considerable area covering, e.g., whole districts, with a possibility of making zero-emission deliveries also between the individual UDs. The research results therefore enable us to give a positive answer to research question RQ2 posed in the Introduction.

Assuming that CTZs expansion in the analysed case study (the city of Szczecin) will proceed evenly and in stages:

- First stage-within a radius of ca. $1 \mathrm{~km}$ from each of the proposed UDs;

- Second stage - within a radius of ca. $2 \mathrm{~km}$ from each of the proposed UDs;

- Third stage-within a radius of ca. $3 \mathrm{~km}$ from each of the proposed UDs.

It will be possible to realize these effects as early as at the second stage, when the areas served by UD Turzyn and UD Niebuszewo partially overlap. The next (third) stage will lead to merging the UD Turzyn and UD Gumieńce zones, which consequently will make it possible to obtain one coherent clean transport zone covering a considerable part of left-bank Szczecin.

The possible spatial expansion of CTZs in Szczecin in the case of applying LFR is presented in Figure 7. 


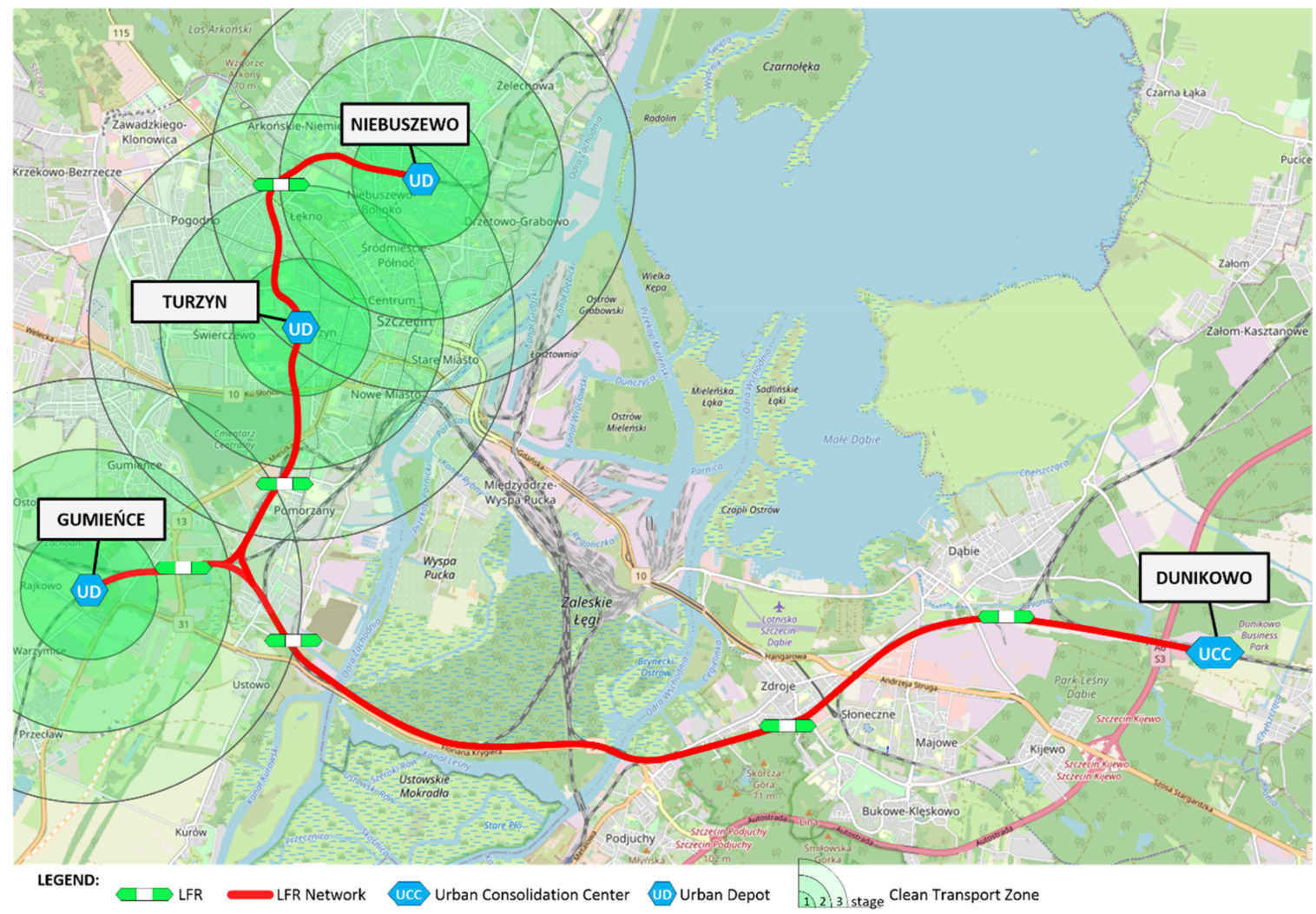

Figure 7. Spatial expansion of CTZs in Szczecin in the case of applying LFR.

It should be noted that incorporation of LFR in the urban delivery system may also bring positive effects outside CTZs. Application of LFR electric trains makes it possible to supplement the zero-emission last-mile delivery system (from UDs to individual customers) with zero-emission deliveries between UCC and the individual UDs. As a result, it is possible to reduce pollutant emissions not only in the specific CTZs (which is the case in variant V0), but also in other areas of the city. The research results therefore enable us to give a positive answer to research question RQ3 posed in the Introduction.

Moreover, it is worth noting that inclusion of LFR trains in the ZUDS in Szczecin will not entail a need to build additional electric infrastructure. All the rail tracks to be used by the planned LFR train routes are provided with electric traction, and as the trains are permanently connected to the power network, there is no need to construct a charging station. These features make it possible to ensure continuity of deliveries to be made with LFR trains to the individual UDs. Thus, as opposed to EFVs, the planning process of deliveries to be made with LFR will not have to provide for technical breaks necessary for battery charging.

\section{Discussion}

The research studies completed for the purposes of this paper made it possible to identify potential possibilities of applying rail transport in the ZUDS. The case study of the city of Szczecin, Poland, was particularly important in view of the adopted research goal. The study made it possible to indicate effects ensuing from shifting urban deliveries from road to rail transport, and in particular to estimate the possible level of external costs reduction resulting from application of the proposed solution.

The computations of external costs generated by the means of transport for the two adopted research variants (V0 and V1) showed that completion of 1 DC by LFR trains makes it possible to reduce transport external costs by $422.01 \mathrm{EUR}$ and to eliminate 30 deliveries made by LCVs in Szczecin, covering the total distance of $1208 \mathrm{~km}$. It is worth noting that depending on the needs and volume of cargo flows in the city, the number of DCs may be 
successively increased, which implies that the obtainable level of transport external costs reduction may rise considerably.

Application of the original concept of incorporating LFR into the ZUDS may also bring other positive effects for the city and its residents. The key benefits identified in the study process are decreased traffic congestion and decreased number of accidents, thus leading to increased road safety, decreased level of road infrastructure degradation, traffic calming, and uncluttering of the urban transport system, together with the possibility of managing the public space in a resident-friendly manner. Another significant effect ensuing from incorporating rail transport into the ZUDS, which was identified in the course of the study, is different locations of UDs and a different manner of serving them, which makes it possible for CTZs to expand more evenly in terms of space.

However, it should be stressed that obtaining the particular effects is also connected with specific limitations. In particular, these include:

- Concerning the level of external costs reduction-the principles of the given country's energy policy, including especially the share of renewable energy sources (RES) in the energy mix. The impact of the RES share on the possibility of obtaining the assumed effects of electromobility in Poland is described in Pietrzak et al. [111,112].

- Regarding measures related to establishing CTZs and introduction of vehicle traffic constraints - the assumptions of the local and national transport policies;

- Engagement of individual stakeholders in changing the urban delivery system, in particular: city authorities, suppliers and shippers;

- The state of the railway infrastructure-it is a precondition for the possibility of applying rail transport in the urban delivery system; especially in terms of its quantitative and qualitative status and the railway electrification level.

- In case the railway network is shared by freight and passenger transport, it is necessary to include LFR in the timetable to assure that passenger transport is undisturbed.

- Rail transport operators will need to purchase appropriate means of transport-the means of transport proposed in the LFR concept are not used on the transport market at the moment.

Moreover, incorporation of rail transport into the ZUDS in Szczecin, via application of LFR electric trains, may provide significant support in view of implementation of the SUFT assumptions and the electromobility policy in the analysed city. Given that in both research variants (V0 and V1) last-mile deliveries from UDs and end customers are to be made with LEFVs and NMT, application of LFR electric trains to handle cargo flows between the UCC and the UDs will make it possible to expand the ZUDS. Consequently, it will be possible to make zero-emission deliveries over the whole UCC-UD-end customer route.

The urban delivery systems for variant V0 and variant V1 are outlined in Figure 8. The blocks in white denote deliveries made with diesel-powered vehicles, whereas the blocks in green show deliveries made with zero-emission vehicles.

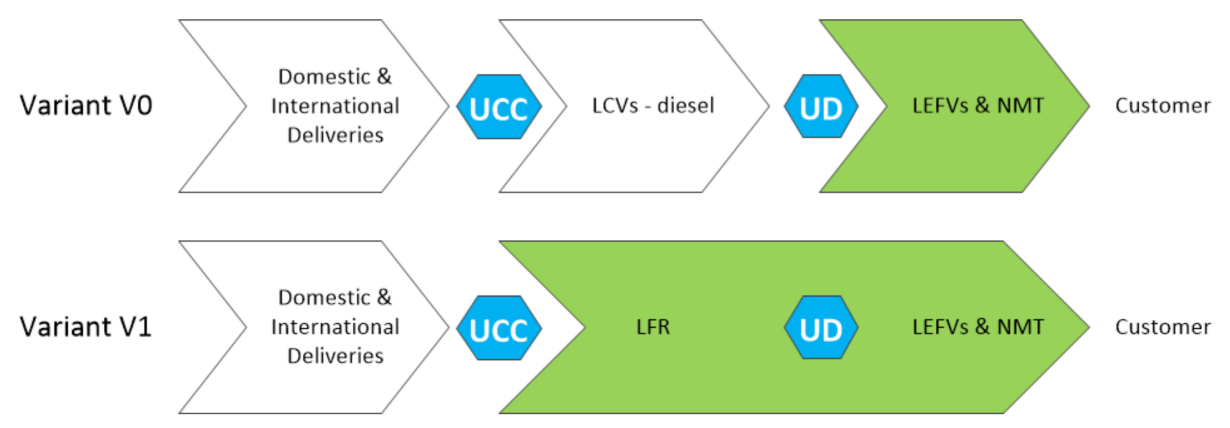

Figure 8. Diagrams of urban delivery systems for variants V0 and V1. 


\section{Conclusions}

The dynamic and often uncontrolled growth of cargo and passenger flows in cities, being the result of urbanisation processes, generates a number of phenomena that are adverse for the natural environment and humans. Counteracting these negative effects requires taking specific measures. One of the solutions applied on an international scale is decarbonisation of transport, which includes its electrification.

The literature addresses this issue to a very broad extent; however, it seems that the vast majority of the deliberations pertain to road transport solutions. In view of the available research results in that respect, it should be underlined that EVs are unable to solve all problems encountered by cities as a result of excessive growth of transport. Although application of EVs does reduce pollution and noise emissions [113], it does not relieve cities from problems such as road congestion, road accidents, and urban infrastructure and greenery degradation. Moreover, EVs are characterised by specific limitations that significantly determine their utilisation. These include in particular the limited battery capacity, the limited travel range, and the need to plan routes in a way that provides time necessary to charge the battery. Many authors also point out the possible future problem with disposal of used batteries [114,115].

As already mentioned above, despite numerous studies on electromobility in transport, the problem of applying rail transport in an urban delivery system is addressed in the literature only to a negligible extent. This paper provides some theoretical value by addressing the issue of effects of incorporating rail transport into a ZUDS by using the LFR concept; thus, it fills the existing literature gap. This issue is particularly important due to the fact that the means of rail transport have been using electric power as the basic drive for many years, and they could (or even should, as demonstrated in the article) be considered as a tool for implementing the idea of urban transport decarbonisation and electromobility.

Analysing the possibilities of using the original concept of LFR, based on the use of dedicated electric vehicles, it was demonstrated that rail transport has potential for its incorporation into the urban delivery system, and it may provide significant support for zero-emission last-mile deliveries in city areas. In particular, the research studies carried out in connection with this paper made it possible to formulate the following conclusions:

- Application of rail transport in the urban delivery system by replacing, on the routes between the UCC and the individual UDs, the LCVs with LFR electric trains, will make it possible to reduce the external costs of transport, decrease the number of vehicles on the streets, and reduce the traffic congestion, which consequently will increase the safety of road traffic participants as well as pedestrians and cyclists.

- Application of rail transport in the urban delivery system may have an influence on development of Clean Transport Zones (CTZs) in the city. LFR trains, being zero-emission vehicles, may enter CTZs, therefore they do not constrain their spatial development; CTZs may expand evenly, regardless of the original locations of UDs.

- Application of LFR may become a factor facilitating expansion of the ZUDS. Application of LFR electric trains between the UCC and the individual UDs provides a possibility of extending zero-emission deliveries in the city also beyond the CTZs.

The research described in this paper also has some practical value. Incorporating rail transport into the ZUDS by applying LFR electric trains may contribute to SUFT development, and consequently to reduction in adverse effects generated by UFT, and achieving the assumptions of the transport electromobility policy. The LFR system is autonomous; therefore, it may be implemented in a given city regardless of the systems applied in other cities. Its application may have an impact on changing the local transport policy and achieving a coherent, zero-emission system of cargo and passenger flow handling in cities.

The issues tackled in this paper require further studies on the determinants of introducing the proposed solutions in specified cities and the ensuing effects.

Author Contributions: Conceptualization, K.P., O.P. and A.M.; data curation, K.P., O.P. and A.M.; formal analysis, K.P., O.P. and A.M.; investigation, K.P. and O.P.; methodology, K.P., O.P. and A.M.; 
visualization, K.P.; writing—original draft, K.P., O.P. and A.M.; writing—review and editing, O.P. All authors have read and agreed to the published version of the manuscript.

Funding: The research presented in this article was carried out in the Maritime University of Szczecin under the Grant 1/S/KGMiST/2021 "Transport 4.0".

Institutional Review Board Statement: Not applicable.

Informed Consent Statement: Not applicable.

Data Availability Statement: Not applicable.

Conflicts of Interest: The authors declare no conflict of interest.

\section{Abbreviations}

The following abbreviations are used in this manuscript:

AEAF Act on Electromobility and Alternative Fuels

CCC Cargo Consolidation Centre

CTZ Clean Transport Zone

DC Delivery Cycle

EFV Electric Freight Vehicle

EU European Union

EV Electric Vehicle

FCC Freight Consolidation Centre

FMU Freight Multiple Units

LCV Light Commercial Vehicle

LDC Local Distribution Centre

LEFV Light Electric Freight Vehicle

LEZ Low Emission Zone

LFR Light Freight Railway

MCC Micro Consolidation Centre

MD Micro Depot

NMT Nonmotorized Transport

PLS Proximity Logistics Space

RES Renewable Energy Sources

SEV Small Sized Electric Vehicle

SMA Szczecin Metropolitan Area

SUFT Sustainable Urban Freight Transport

UCC Urban Consolidation Centre

UCC-ME Urban Consolidation Centre for Municipal Entities

UD Urban Depot

UDC Urban Distribution Centre

UFCC Urban Freight Consolidation Centre

UFT Urban Freight Transport

ZEZ Zero Emission Zone

ZUDS Zero-emission Urban Delivery System

\section{References}

1. Tonne, C.; Adair, L.; Adlakha, D.; Anguelovski, I.; Belesova, K.; Berger, M.; Brelsford, C.; Dadvand, P.; Dimitrova, A.; Giles-Corti, B.; et al. Defining pathways to healthy sustainable urban development. Environ. Int. 2021, 146, 106236. [CrossRef]

2. Ritchie, H.; Roser, M. “Urbanization” Published online at OurWorldInData.org. Available online: https:/ / ourworldindata.org/ urbanization (accessed on 31 May 2021).

3. Kuddus, M.A.; Tynan, E.; McBryde, E. Urbanization: A problem for the rich and the poor? Public Health Rev. 2020, 41, 1-4. [CrossRef] [PubMed]

4. Talla, A.; Ngohe-Ekam, P.S.; Nkeumaleu, A.T. Evaluation of the impact of motorcycles in urban transport on air pollution: A case of douala city in cameroon. J. Sci. Res. Rep. 2018, 20, 1-11. [CrossRef] [PubMed]

5. Georgatzi, V.V.; Stamboulis, Y.; Vetsikas, A. Examining the determinants of $\mathrm{CO}_{2}$ emissions caused by the transport sector: Empirical evidence from 12 European countries. Econ. Anal. Policy 2020, 65, 11-20. [CrossRef]

6. Wang, Y.; Yang, D. Impacts of freight transport on PM2.5 concentrations in China: A spatial dynamic panel analysis. Sustainability 2018, 10, 2865. [CrossRef] 
7. Breuer, J.L.; Samsun, R.C.; Peters, R.; Stolten, D. The impact of diesel vehicles on NOx and PM10 emissions from road transport in urban morphological zones: A case study in North Rhine-Westphalia, Germany. Sci. Total Environ. 2020, 727, 138583. [CrossRef] [PubMed]

8. Lozhkina, O.; Lozhkin, V.; Nevmerzhitsky, N.; Tarkhov, D.; Vasilyev, A. Motor transport related harmful PM2.5 and PM10: From onroad measurements to the modelling of air pollution by neural network approach on street and urban level. J. Phys. Conf. Ser. 2016, 772, 012031. [CrossRef]

9. Boedisantoso, R.; Ciptaningayu, T.N.; Syafei, A.D.; Assomadi, A.F.; Slamet, A.; Hermana, J. Reduction of CO, NOx and SO 2 emissions from the transfer of private vehicles to public transportation: A case study of Surabaya. IOP Conf. Ser. Earth Environ. Sci. 2019, 239, 012041. [CrossRef]

10. Abbasi, M.; Hosseinlou, M.H.; JafarzadehFadaki, S. An investigation of bus rapid transit system (BRT) based on economic and air pollution analysis (Tehran, Iran). Case Stud. Transp. Policy 2020, 8, 553-563. [CrossRef]

11. Robaina, M.; Neves, A. Complete decomposition analysis of $\mathrm{CO}_{2}$ emissions intensity in the transport sector in Europe. Res. Transp. Econ. 2021, 101074. [CrossRef]

12. Giannakis, E.; Serghides, D.; Dimitriou, S.; Zittis, G. Land transport $\mathrm{CO}_{2}$ emissions and climate change: Evidence from Cyprus. Int. J. Sustain. Energy 2020, 39, 634-647. [CrossRef]

13. Santos, G. Road transport and $\mathrm{CO}_{2}$ emissions: What are the challenges? Transp. Policy 2017, 59, 71-74. [CrossRef]

14. Lin, B.; Xie, C. Reduction potential of $\mathrm{CO}_{2}$ emissions in China's transport industry. Renew. Sustain. Energy Rev. 2014, 33, 689-700. [CrossRef]

15. Jereb, B.; Stopka, O.; Skrúcaný, T. Methodology for estimating the effect of traffic flow management on fuel consumption and $\mathrm{CO}_{2}$ production: A case study of Celje, Slovenia. Energies 2021, 14, 1673. [CrossRef]

16. Jacyna, M.; Wasiak, M.; Lewczuk, K.; Karon, G. Noise and environmental pollution from transport: Decisive problems in developing ecologically efficient transport systems. J. Vibroeng. 2017, 19, 5639-5655. [CrossRef]

17. Yang, W.; He, J.; He, C.; Cai, M. Evaluation of urban traffic noise pollution based on noise maps. Transp. Res. Part D Transp. Environ. 2020, 87, 102516. [CrossRef]

18. Raaschou-Nielsen, O.; Andersen, Z.J.; Jensen, S.S.; Ketzel, M.; Sørensen, M.; Hansen, J.; Loft, S.; Tjønneland, A.; Overvad, K. Traffic air pollution and mortality from cardiovascular disease and all causes: A Danish cohort study. Environ. Health 2012, 11, 60. [CrossRef]

19. Jerrett, M.; Shankardass, K.; Berhane, K.; Gauderman, W.J.; Künzli, N.; Avol, E.; Gilliland, F.; Lurmann, F.; Molitor, J.N.; Molitor, J.T.; et al. Traffic-related air pollution and asthma onset in children: A prospective cohort study with individual exposure measurement. Environ. Health Perspect. 2008, 116, 1433-1438. [CrossRef]

20. Samet, J.M. Traffic, Air Pollution, and Health. Inhal. Toxicol. 2007, 19, 1021-1027. [CrossRef]

21. Weichenthal, S.; Hatzopoulou, M.; Goldberg, M.S. Exposure to traffic-related air pollution during physical activity and acute changes in blood pressure, autonomic and micro-vascular function in women: A cross-over study. Part. Fibre Toxicol. 2014, 11, 1-16. [CrossRef]

22. Nguyen-Phuoc, D.Q.; Young, W.; Currie, G.; de Gruyter, C. Traffic congestion relief associated with public transport: State-of-theart. Public Transp. 2020, 12, 455-481. [CrossRef]

23. Caban, J.; Droździel, P. Traffic congestion in chosen cities of Poland. Sci. J. Sil. Univ. Technol. Ser. Transp. 2020, 108, 5-14. [CrossRef]

24. Koźlak, A.; Wach, D. Causes of traffic congestion in urban areas. Case of Poland. SHS Web Conf. 2018, 57, 01019. [CrossRef]

25. Su, Y.; Liu, X.; Li, X. Research on traffic congestion based on system dynamics: The case of Chongqing, China. Complexity 2020, 2020, 1-13. [CrossRef]

26. Bennani, M.; Jawab, F.; Amegouz, D.; Hani, Y.; Elmhamedi, A. The impact of congestion on the cost of transport in urban areas: Application for the location of an urban distribution center. In Proceedings of the 2020 IEEE 13th International Colloquium of Logistics and Supply Chain Management (LOGISTIQUA), Online, 2-4 December 2020. [CrossRef]

27. Rolison, J.J.; Regev, S.; Moutari, S.; Feeney, A. What are the factors that contribute to road accidents? An assessment of law enforcement views, ordinary drivers' opinions, and road accident records. Accid. Anal. Prev. 2018, 115, 11-24. [CrossRef] [PubMed]

28. Timmermans, C.; Alhajyaseen, W.; Al Mamun, A.; Wakjira, T.; Qasem, M.; Almallah, M.; Younis, H. Analysis of road traffic crashes in the State of Qatar. Int. J. Inj. Control. Saf. Promot. 2019, 26, 242-250. [CrossRef]

29. Gopalakrishnan, S. A Public Health Perspective of Road Traffic Accidents. J. Fam. Med. Prim. Care 2021, 1, 144. [CrossRef] [PubMed]

30. Tamakloe, R.; Lim, S.; Sam, E.F.; Park, S.H.; Park, D. Investigating factors affecting bus/minibus accident severity in a developing country for different subgroup datasets characterised by time, pavement, and light conditions. Accid. Anal. Prev. 2021, 159, 106268. [CrossRef] [PubMed]

31. McCahill, C.; Garrick, N. Automobile use and land consumption: Empirical evidence from 12 cities. Urban Des. Int. 2012, 17, 221-227. [CrossRef]

32. Wang, W.; Zhong, M.; Hunt, J. Analysis of the wider economic impact of a transport infrastructure project using an integrated land use transport model. Sustainability 2019, 11, 364. [CrossRef]

33. European Strategy for Low-Emission Mobility. Available online: https://epthinktank.eu/2016/12/19/european-strategy-forlow-emission-mobility/ (accessed on 31 May 2021).

34. Slávik, R.; Beňová, D.; Gnap, J.; Stopka, O. City Logistics and Air Quality. Transp. Commun. 2018, 6, 26-29. [CrossRef] 
35. He, Z.; Haasis, H.D. Integration of urban freight innovations: Sustainable inner-urban intermodal transportation in the retail/postal industry. Sustainability 2019, 11, 1749. [CrossRef]

36. Balint, G.; Branis, M.; Capayova, S.; Hodakova, D.; Zuzulova, A. Multimodal nodes in the system of integrated public transport. In Proceedings of the 20th International Multidisciplinary Scientific GeoConference Proceedings SGEM 2020, Nano, Bio, Green and Space: Technologies for Sustainable Future, Bucharest, Romania, 7-9 July 2020. [CrossRef]

37. Lewandowski, K. The Proposition of amendments to certain laws for the betterment of safety conditions for the supply of goods in the city centre. Transp. Res. Procedia 2016, 16, 288-297. [CrossRef]

38. Waqas, M.; Dong, Q.L.; Ahmad, N.; Zhu, Y.; Nadeem, M. Understanding acceptability towards sustainable transportation behavior: A case study of China. Sustainability 2018, 10, 3686. [CrossRef]

39. Hlali, A.; Wanis, A. Theoretical highlights in container port logistics systems. J. Mar. Island Cult. 2020, 9. [CrossRef]

40. Jacyna, M. The role of the cargo consolidation center in urban logistics system. Int. J. Sustain. Dev. Plan. 2013, 8, 100-113. [CrossRef]

41. Malhene, N.; Trentini, A.; Marques, G.; Burlat, P. Freight consolidation centers for urban logistics solutions: The key role of interoperability. In Proceedings of the 6th IEEE International Conference on Digital Ecosystems and Technologies (DEST), Campione d'Italia, Italy, 18-20 June 2012.

42. Olsson, J.; Woxenius, J. Location of freight consolidation centres serving the city and its surroundings. Procedia-Soc. Behav. Sci. 2012, 39, 293-306. [CrossRef]

43. Triantafyllou, M.K.; Cherrett, T.J.; Browne, M. urban freight consolidation centers. Transp. Res. Rec. J. Transp. Res. Board 2014, 2411, 34-44. [CrossRef]

44. Zhou, Y.; Wang, X. Decision-making process for developing urban freight consolidation centers: Analysis with experimental economics. J. Transp. Eng. 2014, 140, 04013003. [CrossRef]

45. de Oliveira, L.K.; Rocha Macedo, A.D.; Sampaio, J.C.L.; De Oliveira, T.D.P.M.; de Oliveira, R.L.M.; Vieira, J.G.V. Challenges to urban freight transport in historical cities: A case study for Sabará (Brazil). Transp. Res. Procedia 2019, 39, 370-380. [CrossRef]

46. Agrebi, M.; Abed, M.; Omri, M.N. Urban distribution centers location selections problem: A survey. In Proceedings of the 4th International Conference on Advanced Logistics and Transport (ICALT), Valenciennes, France, 20-22 May 2015.

47. Sopha, B.M.; Asih, A.M.S.; Pradana, F.D.; Gunawan, H.E.; Karuniawati, Y. Urban distribution center location. Int. J. Eng. Bus. Manag. 2016, 8, 184797901667837. [CrossRef]

48. van Rooijen, T.; Quak, H. Local impacts of a new urban consolidation centre-The case of Binnenstadservice.nl. Procedia-Soc. Behav. Sci. 2010, 2, 5967-5979. [CrossRef]

49. Handoko, S.D.; Lau, H.C.; Cheng, S.F. Achieving economic and environmental sustainabilities in urban consolidation center with bicriteria auction. IEEE Trans. Autom. Sci. Eng. 2016, 13, 1471-1479. [CrossRef]

50. Gogas, M.A.; Nathanail, E. Evaluation of urban consolidation centers: A methodological framework. Procedia Eng. 2017, 178, 461-471. [CrossRef]

51. Björklund, M.; Johansson, H. Urban consolidation centre-A literature review, categorisation, and a future research agenda. Int. J. Phys. Distrib. Logist. Manag. 2018, 48, 745-764. [CrossRef]

52. Isa, S.S.; Lima, O.F.; Vidal Vieira, J.G. Urban consolidation centers: Impact analysis by stakeholder. Res. Transp. Econ. 2021, 101045. [CrossRef]

53. Allen, J.; Browne, M.; Woodburn, A.; Leonardi, J. The role of urban consolidation centres in sustainable freight transport. Transp. Rev. 2012, 32, 473-490. [CrossRef]

54. Nordtømme, M.E.; Bjerkan, K.Y.; Sund, A.B. Barriers to urban freight policy implementation: The case of urban consolidation center in Oslo. Transp. Policy 2015, 44, 179-186. [CrossRef]

55. Paddeu, D. The bristol-bath urban freight consolidation centre from the perspective of its users. Case Stud. Transp. Policy 2017, 5, 483-491. [CrossRef]

56. Van Duin, J.; Quak, H.; Muñuzuri, J. New challenges for urban consolidation centres: A case study in The Hague. Procedia-Soc. Behav. Sci. 2010, 2, 6177-6188. [CrossRef]

57. Van Heeswijk, W.; Larsen, R.; Larsen, A. An urban consolidation center in the city of Copenhagen: A simulation study. Int. J. Sustain. Transp. 2019, 13, 675-691. [CrossRef]

58. Correia, V.D.A.; Oliveira, L.K.D.; Guerra, A.L. Economical and environmental analysis of an urban consolidation center for Belo Horizonte City (Brazil). Proc-Soc. Behav. Sci. 2012, 39, 770-782. [CrossRef]

59. Firdausiyah, N.; Taniguchi, E.; Qureshi, A.G. Impacts of urban consolidation centres for sustainable city logistics using adaptive dynamic programming based multi-agent simulation. IOP Conf. Ser. Earth Environ. Sci. 2019, 328, 012071. [CrossRef]

60. Roca-Riu, M.; Estrada, M.; Fernández, E. An evaluation of urban consolidation centers through continuous analysis with non-equal market share companies. Transp. Res. Procedia 2016, 12, 370-382. [CrossRef]

61. Wagner, N.; Iwan, S.; Kijewska, K. The assumptions, conditions and barriers of the development of the urban consolidation centre for municipal entities (UCC-ME). Eur. Res. Stud. J. 2021, 24, 806-821. [CrossRef]

62. Cano, A.; Arévalo, P.; Benavides, D.; Jurado, F. Sustainable tramway, techno-economic analysis and environmental effects in an urban public transport. A comparative study. Sustain. Energy Grids Netw. 2021, 26, 100462. [CrossRef]

63. Pirouz, H.M.; Hajizadeh, A. A highly reliable propulsion system with onboard uninterruptible power supply for train application: Topology and control. Sustainability 2020, 12, 3943. [CrossRef] 
64. de Langhe, K.; Meersman, H.; Sys, C.; van de Voorde, E.; Vanelslander, T. How to make urban freight transport by tram successful? J. Shipp. Trade 2019, 4,1-23. [CrossRef]

65. Pietrzak, O.; Pietrzak, K. Cargo tram in freight handling in urban areas in Poland. Sustain. Cities Soc. 2021, 70, 102902. [CrossRef]

66. Bartłomiejczyk, M.; Połom, M. Possibilities for developing electromobility by using autonomously powered trolleybuses based on the example of Gdynia. Energies 2021, 14, 2971. [CrossRef]

67. Bartłomiejczyk, M.; Połom, M. Sustainable use of the catenary by trolleybuses with auxiliary power sources on the example of Gdynia. Infrastructures 2021, 6, 61. [CrossRef]

68. Wołek, M.; Szmelter-Jarosz, A.; Koniak, M.; Golejewska, A. Transformation of trolleybus transport in Poland. Does In-Motion Charging (Technology) Matter? Sustainability 2020, 12, 9744. [CrossRef]

69. Połom, M. Technology development and spatial diffusion of auxiliary power sources in trolleybuses in european countries. Energies 2021, 14, 3040. [CrossRef]

70. Borowska-Stefańska, M.; Kowalski, M.; Kurzyk, P.; Mikušová, M.; Wiśniewski, S. Privileging electric vehicles as an element of promoting sustainable urban mobility-Effects on the local transport system in a large metropolis in poland. Energies 2021, 14, 3838. [CrossRef]

71. Macioszek, E. Analysis of trends in development of electromobility in Poland: Current problems and issues. In Transport Development Challenges in the 21st Century; Springer International Publishing: Cham, Switzerland, 2021; pp. 145-156.

72. Sierpiński, G.; Pijoan, A.; Turon, K.; Staniek, M. Challenges Related to the Implementation and Development of Electromobility in Cities. In Transport Development Challenges in the 21st Century; Springer International Publishing: Cham, Switzerland, 2021; pp. 203-213.

73. Feckova Skrabulakova, E.; Ivanova, M.; Rosova, A.; Gresova, E.; Sofranko, M.; Ferencz, V. On electromobility development and the calculation of the infrastructural country electromobility coefficient. Processes 2021, 9, 222. [CrossRef]

74. Holman, C.; Harrison, R.; Querol, X. Review of the efficacy of low emission zones to improve urban air quality in European cities. Atmos. Environ. 2015, 111, 161-169. [CrossRef]

75. Zhai, M.; Wolff, H. Air pollution and urban road transport: Evidence from the world's largest low-emission zone in London. Environ. Econ. Policy Stud. 2021, 23, 721-748. [CrossRef]

76. Tretvik, T.; Nordtømme, M.E.; Bjerkan, K.Y.; Kummeneje, A.M. Can low emission zones be managed more dynamically and effectively? Res. Transp. Bus. Manag. 2014, 12, 3-10. [CrossRef]

77. Morfeld, P.; Groneberg, D.A.; Spallek, M.F. Effectiveness of low emission zones: Large scale analysis of changes in environmental NO2, NO and NOx concentrations in 17 german cities. PLoS ONE 2014, 9, e102999. [CrossRef]

78. Peters, J.F.; Burguillo, M.; Arranz, J.M. Low emission zones: Effects on alternative-fuel vehicle uptake and fleet $\mathrm{CO}_{2}$ emissions. Transp. Res. Part D Transp. Environ. 2021, 95, 102882. [CrossRef]

79. de Bok, M.; Tavasszy, L.; Kourounioti, I.; Thoen, S.; Eggers, L.; Nielsen, V.M.; Streng, J. Simulation of the impacts of a zero-emission zone on freight delivery patterns in Rotterdam. Transp. Res. Rec. J. Transp. Res. Board 2021, 036119812110126. [CrossRef]

80. Act of 11 January 2018 on Electromobility and Alternative Fuels (Ustawa z dnia 11 stycznia 2018 r. o elektromobilności i paliwach alternatywnych, Dz. U. 2018, poz. 317). Available online: https:/ /isap.sejm.gov.pl (accessed on 31 May 2021).

81. Quak, H.; Nesterova, N.; van Rooijen, T. Possibilities and barriers for using electric-powered vehicles in city logistics practice. Transp. Res. Procedia 2016, 12, 157-169. [CrossRef]

82. Dong, Y.; Polak, J.; Tretvik, T.; Roche-Cerasi, I.; Quak, H.; Nesterova, N.; Van Rooijen, T. Electric freightvehicles for urban logistics-Technical performance, economics feasibility and environmental impacts. In Proceedings of the 7th Transport Research Arena TRA 2018, Vienna, Austria, 16-19 April 2018. [CrossRef]

83. Szczepański, E. The freight transport effectiveness assessment in the aspect of the use of environmentally friendly vehicles. $J$. KONES 2019, 25, 405-414.

84. İMre, K.; ÇElebi, D.; Koca, F. Understanding barriers and enablers of electric vehicles in urban freight transport: Addressing stakeholder needs in Turkey. Sustain. Cities Soc. 2021, 68, 102794. [CrossRef]

85. Melo, S.; Baptista, P.; Costa, L. Comparing the use of small sized electric vehicles with diesel vans on city logistics. Procedia-Soc. Behav. Sci. 2014, 111, 1265-1274. [CrossRef]

86. Moolenburgh, E.; van Duin, J.; Balm, S.; van Altenburg, M.; van Amstel, W.P. Logistics concepts for light electric freight vehicles: A multiple case study from the Netherlands. Transp. Res. Procedia 2020, 46, 301-308. [CrossRef]

87. Balm, S.; Moolenburgh, E.; Anand, N.; Van Amstel, W.P. The potential of light electric vehicles for specific freight flows: Insights from the Netherlands. City Logist. 2018, 2, 241-260.

88. Skrúcaný, T.; Kendra, M.; Stopka, O.; Milojević, S.; Figlus, T.; Csiszár, C. Impact of the electric mobility implementation on the greenhouse gases production in central european countries. Sustainability 2019, 11, 4948. [CrossRef]

89. Csiszár, C.; Pauer, G. Concept of an integrated mobile application aiding electromobility. Transport 2019, 34, 187-194. [CrossRef]

90. Naumov, V.; Pawluś, M. Identifying the optimal packing and routing to improve last-mile delivery using cargo bicycles. Energies 2021, 14, 4132. [CrossRef]

91. Vasiutina, H.; Naumov, V. Evaluation of the transport impact on environmental pollution due to the use of cargo bikes. Lect. Notes Netw. Syst. 2021, 570-579. [CrossRef]

92. Balm, S.; Ploos van Amstel, W. Assessing the potential market for cargo bikes by providing a better understanding of urban freight transport. In Proceedings of the European Cycle Logistics Conference. ECLF 2017, Vienna, Austria, 20-21 March 2017. [CrossRef] 
93. Dybdalen, D.; Ryeng, E.O. Understanding how to ensure efficient operation of cargo bikes on winter roads. Res. Transp. Bus. Manag. 2021, 100652. [CrossRef]

94. Gupta, S. Role of Non -motorized transport in distribution of goods in the metropolitan city of Delhi. Transp. Res. Procedia 2017, 25, 978-984. [CrossRef]

95. Elbert, R.; Friedrich, C. Urban consolidation and cargo bikes: A simulation study. Transp. Res. Procedia 2020, 48, 439-451. [CrossRef]

96. Meryem, O.; Saad, L.E.; Mohamed, K.; Fouad, J. Review of good practices in urban freight transportation and benchmarking city logistics schemes. In Proceedings of the 2019 International Colloquium on Logistics and Supply Chain Management (LOGISTIQUA), Montreuil—Paris, France, 12-14 June 2019. [CrossRef]

97. Montwiłl, A.; Pietrzak, O.; Pietrzak, K. The role of Integrated Logistics Centers (ILCs) in modelling the flows of goods in urban areas based on the example of Italy. Sustain. Cities Soc. 2021, 69, 102851. [CrossRef]

98. Bosona, T. Urban freight last mile logistics-Challenges and opportunities to improve sustainability: A literature review. Sustainability 2020, 12, 8769. [CrossRef]

99. Enthoven, D.L.; Jargalsaikhan, B.; Roodbergen, K.J.; uit het Broek, M.A.; Schrotenboer, A.H. The two-echelon vehicle routing problem with covering options: City logistics with cargo bikes and parcel lockers. Comput. Oper. Res. 2020, 118, 104919. [CrossRef]

100. Hof, J.; Schneider, M. Intraroute resource replenishment with mobile depots. Transp. Sci. 2021, 55, 660-686. [CrossRef]

101. Gonzalez-Feliu, J. A joint freight catchment and cost benefit analysis to assess rail urban logistics scenarios. Lect. Notes Bus. Inf. Process. 2018, 14-27. [CrossRef]

102. Diziain, D.; Taniguchi, E.; Dablanc, L. Urban Logistics by Rail and Waterways in France and Japan. Procedia-Soc. Behav. Sci. 2014, 125, 159-170. [CrossRef]

103. Kelly, J.; Marinov, M. Innovative Interior Designs for Urban Freight Distribution Using Light Rail Systems. Urban Rail Transit 2017, 3, 238-254. [CrossRef]

104. Pietrzak, K. Analysis of the possibilities of using "Light Freight Railway" for the freight transport implementation in agglomeration areas (example of West Pomerania Province). Transp. Res. Procedia 2016, 16, 464-472. [CrossRef]

105. Pietrzak, O.; Pietrzak, K. The role of railway in handling transport services of cities and agglomerations. Transp. Res. Procedia 2019, 39, 405-416. [CrossRef]

106. Pietrzak, K.; Pietrzak, O.; Montwiłł, A. Light Freight Railway (LFR) as an innovative solution for Sustainable Urban Freight Transport. Sustain. Cities Soc. 2021, 66, 102663. [CrossRef]

107. Handbook on the External Costs of Transport. Version 2019-1.1. European Commission, Brussels. 2019. Available online: https:/ / op.europa.eu/en/publication-detail/- / publication/9781f65f-8448-11ea-bf12-01aa75ed71a1 (accessed on 31 May 2021).

108. Local Data Bank. Available online: https:/ /bdl.stat.gov.pl/BDL/start (accessed on 31 May 2021).

109. General Land Use Plan for the City of Szczecin, Office for Urban Spatial Planning in Szczecin. Available online: bip.um.szczecin.pl (accessed on 31 May 2021).

110. TransportPolicy.net. Available online: www.transportpolicy.net/standard/eu-vehicle-definitions (accessed on 31 May 2021).

111. Pietrzak, K.; Pietrzak, O. Environmental effects of electromobility in a sustainable urban public transport. Sustainability 2020, 12, 1052. [CrossRef]

112. Pietrzak, O.; Pietrzak, K. The economic effects of electromobility in sustainable urban public transport. Energies 2021, 14, 878. [CrossRef]

113. Iwan, S.; Allesch, J.; Celebi, D.; Kijewska, K.; Hoé, M.; Klauenberg, J.; Zajicek, J. Electric mobility in European urban freight and logistics-Status and attempts of improvement. Transportation Research Procedia 2019, 39, 112-123. [CrossRef]

114. Janota, L.; Králík, T.; Knápek, J. Second life batteries used in energy storage for frequency containment reserve service. Energies 2020, 13, 6396. [CrossRef]

115. Haram, M.H.S.M.; Lee, J.W.; Ramasamy, G.; Ngu, E.E.; Thiagarajah, S.P.; Lee, Y.H. Feasibility of utilising second life EV batteries: Applications, lifespan, economics, environmental impact, assessment, and challenges. Alex. Eng. J. 2021, 60, 4517-4536. [CrossRef] 